\title{
The potential of selected Australian medicinal plants with anti-Proteus activity for the treatment and prevention of rheumatoid arthritis
}

\author{
I. E. Cock ${ }^{1,2}$, V. Winnett ${ }^{2}$, J. Sirdaarta ${ }^{1,2}$, B. Matthews ${ }^{3}$ \\ ${ }^{1}$ Environmental Futures Research Institute, Nathan Campus, Griffith University, ${ }^{2}$ School of Natural Sciences, Nathan Campus, Griffith \\ University, Nathan, Queensland 4111, ${ }^{3}$ Smartwaters Research Centre, Griffith University, Gold Coast, Australia
}

Submitted: 01-08-2014

Revised: 18-09-2014

Published: 27-05-2015

A B S TR A C T

Background: A wide variety of herbal medicines are used in indigenous Australian traditional medicinal systems to treat rheumatoid arthritis (RA) and inflammation. The current study was undertaken to test the ability of a panel of Australian plants with a history of the ethnobotanical usage in the treatment of inflammation for the ability to block the microbial trigger of RA. Materials and Methods: One hundred and six extracts from 40 plant species were investigated for the ability to inhibit the growth of the bacterial trigger of RA (Proteus mirabilis). The extracts were tested for toxicity in the Artemia nauplii bioassay. The most potent inhibitor of P. mirabilis growth was further analyzed by reversed-phase high performance liquid chromatography (RP-HPLC) coupled to high accuracy time-of-flight (TOF) mass spectroscopy. Results: Sixty-five of the 106 extracts tested (61.3\%) inhibited the growth of P. The Aleurites moluccanus, Datura leichardtii, Eucalyptus major, Leptospermum bracteata, L. juniperium, Macadamia integriflora nut, Melaleuca alternifolia, Melaleuca quinquenervia, Petalostigma pubescens, P. triloculorae, $P$. augustifolium, Scaevola spinescens, Syzygium australe, and Tasmannia lanceolata extracts were determined to be the most effective inhibitors of $P$. mirabilis growth, with minimum inhibitory concentration (MIC) values generally significantly below $1000 \mu \mathrm{g} / \mathrm{ml}$. T. lanceolata fruit extracts were the most effective $P$. mirabilis growth inhibitors, with a MIC values of 11 and $126 \mu \mathrm{g} / \mathrm{ml}$ for the methanolic and aqueous extracts, respectively. Subsequent analysis of the $T$. lanceolata fruit extracts by RP-HPLC coupled to high-resolution TOF mass spectroscopy failed to detect resveratrol in either T. lanceolata fruit extract. However, the resveratrol glycoside piceid and 2 combretastatin stilbenes (A-1 and A-4) were detected in both $T$. lanceolata fruit extracts. With the exception of the Eucalyptus and Syzygium extracts, all extracts exhibiting Proteus inhibitory activity were also shown to be nontoxic, or of low toxicity in the Artemia nauplii bioassay. Conclusions: The low toxicity of these extracts and their inhibitory bioactivity against Proteus spp. indicate their potential in blocking the onset of rheumatoid arthritis.

Key words: Australian plants, combretastatin, inflammation, Piceid, Proteus mirabilis, resveratrol, rheumatoid arthritis, stilbene

\section{INTRODUCTION}

Autoimmune inflammatory disorders (AIID's) are a group of debilitating conditions including rheumatoid arthritis (RA), ankylosing spondylitis, lupus and multiple sclerosis, which afflict genetically susceptible individuals. There is no common susceptibility profile for these disorders. RA, for example, is most prevalent in middle-aged to older women,

Address for correspondence:

Dr. I. E. Cock, Environmental Futures Research Institute, Nathan

Campus, Griffith University, 170 Kessels Road, Nathan,

Queensland 4111, Australia.

E-mail: i.cock@griffith.edu.au

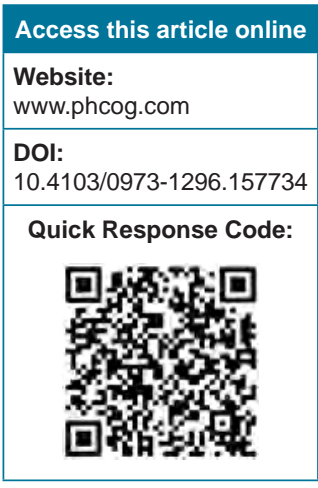

whereas the onset of ankylosing spondylitis occurs most frequently in younger males..$^{[1]}$ There are currently no cures for any of these conditions and current treatment strategies aim to alleviate the symptoms (particularly pain and swelling) via the use of analgesics and anti-inflammatory agents, and/or to modify the disease process through the use of disease-modifying anti-rheumatic drugs (DMARDs). None of these treatments are ideal as prolonged usage of these drugs can result in unwanted side effects and toxicity. ${ }^{[2]}$ There is a need to develop safer, more effective drugs for the treatment of inflammatory diseases which will not only alleviate the symptoms, but which may also cure or prevent the disease. 
Eradication of the cause of an inflammatory disease is an attractive target for drug design as this would not only block/decrease the late-phase inflammatory symptoms, but would also block the immune response and subsequent tissue damage associated with AIID's. While the causes of RA are not comprehensively understood, it is generally accepted that it is an autoimmune disorder which is triggered by specific microbial infections in genetically susceptible individuals (individuals with the MHC class 2 allele HLA-DR4). ${ }^{[3]}$ Proteus mirabilis infections have been proposed to trigger RA based on several lines of evidence:

- Elevated serum levels of P. mirabilis specific cross-reactive antibodies have frequently been reported in individuals suffering from $\mathrm{RA}^{[4-9]}$

- P. mirabilis antibodies from RA patients have cytopathic effects on joint tissue possessing P. mirabilis cross-reactive antibodies ${ }^{[10]}$

- P. mirabilis infections have been frequently reported in urine samples from patients with $\mathrm{RA}^{[11]}$

- Sera from rabbits immunized with HLA-DR4 positive lymphocytes bind specifically to Proteus ${ }^{[12]}$

- Amino acid sequence homologies have been identified between the "EQ/KRRAA" motif present in RA HLA-susceptibility antigens and the "ESRRAL" amino acid sequence present in $P$. mirabilis hemolysins ${ }^{[13]}$

- A further sequence homology between the "LRREI" sequence of type XI collagen (present in joint cartilage) and the "IRRET" motif present in P. mirabilis urease enzyme has also been reported. ${ }^{[14]}$

Based on the evidence linking Proteus bacterial infections with pathogenesis, a mechanism of RA disease progression has been proposed [Figure 1]: Gastrointestinal P. mirabilis acts as a trigger for RA. ${ }^{[10]}$ Thus, limiting the levels of gastrointestinal P. mirabilis (1) would prevent RA initiation and minimize its downstream effects. Gastrointestinal P. mirabilis will not initiate the autoimmune events associated with RA unless it is able to interact with the immune system. This most often results from urinary tract infections (2) or when epithelial lesions (or other epithelial interruptions) allow for the production of anti-P. mirabilis antibodies. ${ }^{[10,15]}$ Inhibition of the causative agents of gut lesion forming conditions (e.g. Crohn's disease) would also be expected to decrease RA initiation events. Furthermore, prevention and early detection of urinary tract infections (UTIs) (the major pathway for interaction of P. mirabilis with the immune system) and/or the colonization of the bladder (2 and 3) would block the onset of RA and lessen downstream effects. Blocking the immune response by blocking the interaction of $P$. mirabilis with immunological cells (4) or by immunomodulation (5) also prevents the production of self-reactive antibodies (6) or the cross-reactivity with

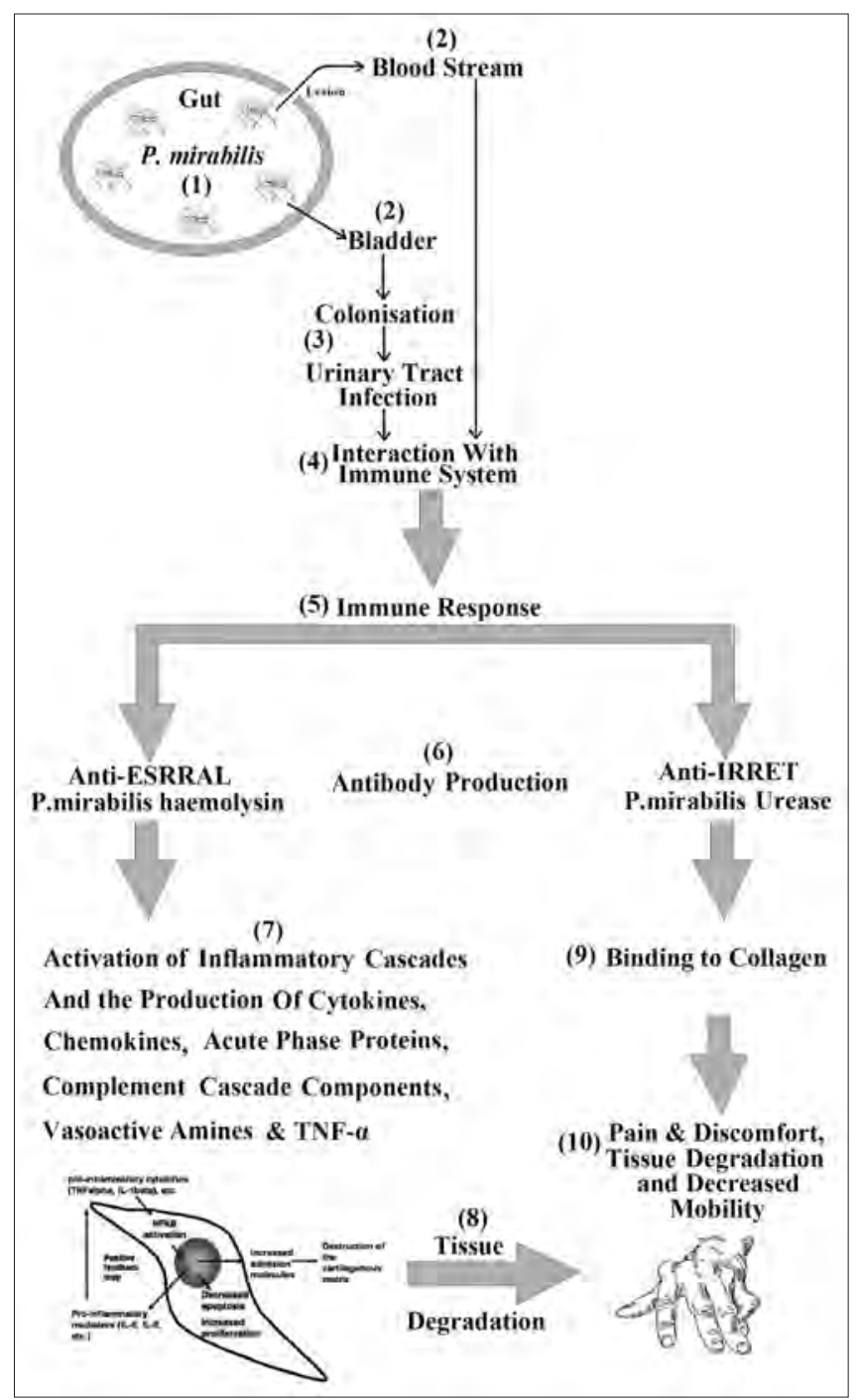

Figure 1: A proposed schematic representation of the main events in rheumatoid arthritis (RA) disease etiology and progression. Only major events are shown. Numbers refer to current and/or proposed targets for the prevention and treatment of RA

self-tissue, (9) thereby diminishing the later phase events of RA and thus the disease symptoms (10). However, immunomodulatory therapy should be used with caution as inhibiting the patient's immune capability would also expose the patient to a variety of other infections. Most current RA therapies target the later phase events by (7) blocking the inflammatory cascades or (8 and 10) by decreasing the symptoms of RA (e.g. pain, swelling, heat). While drugs targeting the late events are effective in easing patient discomfort, they still allow the tissue damage (which is associated with the self-reactive antibody action) to occur. Targeting earlier events prior to the induction of the immune response would not only alleviate the symptoms and discomfort of RA, but would also lessen/prevent the joint damage associated with chronic inflammation. 
Targeting P. mirabilis infections may provide a new therapeutic approach for preventing and treating RA. One strategy is the development of anti-Proteus vaccines. While the production of a vaccine may block Proteus pathogenesis, it is also a problematic approach as anti-Proteus antibodies would also be likely to cross-react with the host connective tissue in susceptible individuals and thus exacerbate the symptoms of RA. If antibodies lacking cross-reactive epitopes are developed in the future, this approach may be effective as it would block susceptible individuals from acquiring a Proteus infection, thus effectively blocking RA progression. However, the development and usage of Proteus sensitive antibiotics may prove a more effective means of treating the RA bacterial trigger and thus blocking this disease. By destroying the Protens bacteria, this treatment modality would be expected to greatly reduce the impact of the bacteria and the production of anti-Proteus antibodies and thus decrease disease progression.

Many antibiotics are already known to inhibit Proteus growth and/or have bactericidal effects toward Proteus spp. However, the development of super-resistant bacterial strains has resulted in currently used antibiotic agents failing to end many bacterial infections. ${ }^{[16,17]}$ For this reason, the development of new anti-P. mirabilis chemotherapeutic agents for the prevention and treatment of RA has received recent attention. Recent studies have examined the anti-P. mirabilis activity of conventional antimicrobials such as carbapenems ${ }^{[18]}$ and of complementary and alternative therapies including nano-metallic preparations ${ }^{[19]}$ and traditional South African medicinal plants. ${ }^{[20]}$ A re-examination of traditional medicines for the treatment of inflammation and rheumatic conditions is an attractive prospect as the antiseptic qualities of medicinal plants have been long recognized and recorded. Furthermore, there has recently been a revival of interest in herbal medications due to a perception that there is a lower incidence of adverse reactions to plant preparations compared to synthetic pharmaceuticals.

In this study, a selection of Australian plants was identified which were traditionally used for the treatment of RA as well as other inflammatory conditions [Table 1]. While the ethnobotanical uses of these plants in traditional Aboriginal medicine systems have been recorded, rigorous scientific studies are lacking for many species. We were

\begin{tabular}{|c|c|c|c|c|c|}
\hline Plant species & Common name & $\begin{array}{l}\text { Part used } \\
\text { medicinally }\end{array}$ & $\begin{array}{l}\text { Part used in } \\
\text { this study }\end{array}$ & Medicinal use & References \\
\hline Acacia auriculiformis & $\begin{array}{l}\text { Earleaf acacia, } \\
\text { earpod wattle, } \\
\text { northern black wattle, } \\
\text { tan wattle }\end{array}$ & Leaves & Leaves & Allergy, antiseptic, rash & [21] \\
\hline Acacia diasparima & $\begin{array}{l}\text { Hickory wattle, until } \\
\text { recently known as } \\
\text { Acacia aulacocarpa }\end{array}$ & Leaves & Leaves & Allergy, antiseptic, rash & {$[21,25,27]$} \\
\hline Acacia leptoloba & Irvine bank wattle & Leaves & Leaves & Allergy, antiseptic, sore eyes, rash & [21] \\
\hline Aleurites moluccanus & $\begin{array}{l}\text { Candlenut, Indian } \\
\text { walnut, varnish tree }\end{array}$ & $\begin{array}{l}\text { Leaves, nut, } \\
\text { bark }\end{array}$ & Nut & Rheumatism, swelling, inflammation & [22] \\
\hline Alphitonia excelsa & Red ash, soap tree & Leaves, nut & Leaves & $\begin{array}{l}\text { Antimicrobial (especially skin microbes/skin } \\
\text { sores), rheumatism, swelling, inflammation }\end{array}$ & {$[21,22]$} \\
\hline Alpinia caerulea & Native ginger & $\begin{array}{l}\text { Roots, } \\
\text { leaves, fruit }\end{array}$ & Fruit, leaves & $\begin{array}{l}\text { Young tips of roots are edible and have } \\
\text { similar medicinal properties to Ziniber } \\
\text { officinale (ginger), especially inflammation, } \\
\text { nausea, arthritis, slowing cancer growth }\end{array}$ & {$[21,22]$} \\
\hline Backhousia citriodora & $\begin{array}{l}\text { Lemon myrtle, lemon } \\
\text { scented myrtle, lemon } \\
\text { scented ironwood }\end{array}$ & Leaves & Leaves & $\begin{array}{l}\text { Antimicrobial (especially skin microbes/ } \\
\text { skin sores), high in essential oils, used for } \\
\text { food flavoring }\end{array}$ & {$[21,62]$} \\
\hline Backhousia myrtiflora & $\begin{array}{l}\text { Cinnamon myrtle, } \\
\text { Australian lancewood, } \\
\text { carrol ironwood, grey } \\
\text { myrtle }\end{array}$ & Leaves & Leaves & $\begin{array}{l}\text { Antimicrobial (especially skin microbes/ } \\
\text { skin sores), high in essential oils, used for } \\
\text { food flavoring }\end{array}$ & [21] \\
\hline Callistemon citrinus & Crimson bottlebrush & Leaves & $\begin{array}{l}\text { Leaves, } \\
\text { flowers }\end{array}$ & $\begin{array}{l}\text { Rheumatism, swellings, inflammation, } \\
\text { skin disorders, treatment of respiratory } \\
\text { infections, antimicrobial }\end{array}$ & {$[21,26,27]$} \\
\hline Callistemon formosus & Cliff bottlebrush & Leaves & Leaves & $\begin{array}{l}\text { Rheumatism, swellings, inflammation, } \\
\text { skin disorders, treatment of respiratory } \\
\text { infections, antimicrobial }\end{array}$ & {$[21,26,27]$} \\
\hline Callistemon salignus & $\begin{array}{l}\text { White bottlebrush, } \\
\text { willow bottlebrush }\end{array}$ & Leaves & $\begin{array}{l}\text { Leaves, } \\
\text { flowers }\end{array}$ & $\begin{array}{l}\text { Rheumatism, swellings, inflammation, } \\
\text { skin disorders, treatment of respiratory } \\
\text { infections, antimicrobial }\end{array}$ & {$[21,26,27]$} \\
\hline
\end{tabular}




\begin{tabular}{|c|c|c|c|c|c|}
\hline Plant species & Common name & $\begin{array}{l}\text { Part used } \\
\text { medicinally }\end{array}$ & $\begin{array}{l}\text { Part used in } \\
\text { this study }\end{array}$ & Medicinal use & References \\
\hline Cinnamomum oliveri & $\begin{array}{l}\text { Camphorwood, } \\
\text { Oliver's sassafrass, } \\
\text { black sassafras, } \\
\text { cinnamon wood }\end{array}$ & $\begin{array}{l}\text { Bark, leaf, } \\
\text { fruit }\end{array}$ & Leaf & $\begin{array}{l}\text { Oils made from the distillation of the bark } \\
\text { are used to treat rheumatism, swellings, } \\
\text { inflammation, skin disorders, antimicrobial }\end{array}$ & {$[21,22]$} \\
\hline Davidsonia pruriens & $\begin{array}{l}\text { Davidson's plum, } \\
\text { ooray }\end{array}$ & Fruit, leaves & Fruit, leaves & $\begin{array}{l}\text { Medicinal activities unknown-included } \\
\text { because of its very high antioxidant activity } \\
\text { (high antioxidant content has been linked } \\
\text { with prevention of chronic diseases) }\end{array}$ & {$[21,23,63]$} \\
\hline Duboisia leichhardtii & $\begin{array}{l}\text { Corkwood, } \\
\text { poisonous corkwood, } \\
\text { Queensland } \\
\text { Duboisia, yellow } \\
\text { basswood }\end{array}$ & Leaves, bark & Leaves & $\begin{array}{l}\text { Treatment of pain, inflammation, nausea } \\
\text { and intestinal problems }\end{array}$ & {$[21,22]$} \\
\hline Elaeocarpus angustifolius & $\begin{array}{l}\text { Blue quandong, blue } \\
\text { fig, blue marble tree }\end{array}$ & Fruit & Fruit & $\begin{array}{l}\text { Medicinal activities unknown-included } \\
\text { because of its very high antioxidant activity } \\
\text { (high antioxidant content has been linked } \\
\text { with prevention of chronic diseases) }\end{array}$ & {$[21,23,63]$} \\
\hline Eucalyptus baileyana & Black stringy bark & $\begin{array}{l}\text { Bark (gum), } \\
\text { leaves }\end{array}$ & Leaves & $\begin{array}{l}\text { Rheumatism, swellings, inflammation, skin } \\
\text { disorders, stomach disorders, bactericide } \\
\text { (wounds, sores), high leaf terpene content }\end{array}$ & {$[21,22,28]$} \\
\hline Eucalyptus major & $\begin{array}{l}\text { Queensland grey } \\
\text { gum }\end{array}$ & $\begin{array}{l}\text { Bark (gum), } \\
\text { leaves }\end{array}$ & Leaves & $\begin{array}{l}\text { Rheumatism, swellings, inflammation, skin } \\
\text { disorders, stomach disorders, bactericide } \\
\text { (wounds, sores), high leaf terpene content }\end{array}$ & {$[21,22,28]$} \\
\hline Kunzea flavescens & Yellow Kunzea & Leaves, fruit & Leaves & $\begin{array}{l}\text { Ethnomedicinal usage unknown, but other } \\
\text { Kunzea species are known to be used in } \\
\text { the treatment of rheumatism, swellings, } \\
\text { inflammation, skin disorders and as a } \\
\text { general antimicrobial }\end{array}$ & {$[21,22]$} \\
\hline $\begin{array}{l}\text { Leptospermum longifolium } \\
\text { (also known as } \\
\text { Leptospermum madidum) }\end{array}$ & Weeping tea tree & Leaf & Leaf & $\begin{array}{l}\text { Rheumatism, swellings, inflammation, skin } \\
\text { disorders, stomach disorders, bactericide } \\
\text { (wounds, sores), high leaf terpene content }\end{array}$ & {$[21,22,29]$} \\
\hline Leptospermum bracteata & Unknown & Leaf & Leaf & $\begin{array}{l}\text { Rheumatism, swellings, inflammation, skin } \\
\text { disorders, stomach disorders, bactericide } \\
\text { (wounds, sores), high leaf terpene content }\end{array}$ & {$[21,22,29,37]$} \\
\hline Leptospermum juniperium & Prickly tea tree & Leaf & Leaf & $\begin{array}{l}\text { Rheumatism, swellings, inflammation, skin } \\
\text { disorders, stomach disorders, bactericide } \\
\text { (wounds, sores), high leaf terpene content }\end{array}$ & {$[21,22,29,37]$} \\
\hline $\begin{array}{l}\text { Leptospermum petersonii } \\
\text { (formerly known as } \\
\text { Leptospermum citratum) }\end{array}$ & $\begin{array}{l}\text { Lemon scented tea } \\
\text { tree }\end{array}$ & Leaf & Leaf & $\begin{array}{l}\text { Rheumatism, swellings, inflammation, skin } \\
\text { disorders, stomach disorders, bactericide } \\
\text { (wounds, sores), high leaf terpene content }\end{array}$ & {$[21,22,29,37]$} \\
\hline Macadamia integriflora & $\begin{array}{l}\text { Macadamia } \\
\text { nut, baupe nut, } \\
\text { Queensland nut }\end{array}$ & Leaf, nut & Leaf, nut & $\begin{array}{l}\text { Ethnomedical uses unknown although the } \\
\text { nut is known to keep well and has been } \\
\text { shown to have antimicrobial properties }\end{array}$ & [64] \\
\hline Melaleuca alternifolia & $\begin{array}{l}\text { Narrow leafed } \\
\text { paperbark, narrow- } \\
\text { leafed tea tree }\end{array}$ & Leaf & leaf & $\begin{array}{l}\text { Rheumatism, swellings, inflammation, skin } \\
\text { disorders, stomach disorders, bactericide } \\
\text { (wounds, sores), STI's, high leaf terpene } \\
\text { content }\end{array}$ & {$[21,22]$} \\
\hline Melaleuca quinquenervia & Tea tree & Leaf & Leaf & $\begin{array}{l}\text { Rheumatism, swellings, inflammation, skin } \\
\text { disorders, stomach disorders, bactericide } \\
\text { (wounds, sores), STI's, high leaf terpene } \\
\text { content }\end{array}$ & {$[21,22]$} \\
\hline Petalostigma pubescens & Quinine bush & $\begin{array}{l}\text { Fruit, bark, } \\
\text { leaf }\end{array}$ & Fruit, leaf & $\begin{array}{l}\text { Inflammation, skin disorders, stomach } \\
\text { disorders, bactericide (wounds, sores), } \\
\text { asthma }\end{array}$ & {$[21,22,34]$} \\
\hline Petalostigma triloculorae & $\begin{array}{l}\text { Long leafed bitter } \\
\text { bark, long leafed } \\
\text { quinine bush }\end{array}$ & $\begin{array}{l}\text { Fruit, bark, } \\
\text { leaf }\end{array}$ & Fruit, leaf & $\begin{array}{l}\text { Inflammation, skin disorders, stomach } \\
\text { disorders, bactericide (wounds, sores), } \\
\text { asthma }\end{array}$ & {$[21,22,34]$} \\
\hline $\begin{array}{l}\text { Pittosporum augustifolium } \\
\text { (previously known } \\
\text { as Pittosporum } \\
\text { phylliraeoides) }\end{array}$ & $\begin{array}{l}\text { Weeping Pittosporum, } \\
\text { butterbush, cattle } \\
\text { bush, native apricot, } \\
\text { gumbi gumbi, cumby } \\
\text { cumby }\end{array}$ & $\begin{array}{l}\text { Fruit, wood, } \\
\text { leaves }\end{array}$ & Leaves & $\begin{array}{l}\text { Pain, inflammation, cough, cold, skin } \\
\text { disorders, reputed to block cancer } \\
\text { proliferation }\end{array}$ & {$[21,22]$} \\
\hline
\end{tabular}




\begin{tabular}{|c|c|c|c|c|c|}
\hline Plant species & Common name & $\begin{array}{l}\text { Part used } \\
\text { medicinally }\end{array}$ & $\begin{array}{l}\text { Part used in } \\
\text { this study }\end{array}$ & Medicinal use & References \\
\hline Scaevola spinescens & $\begin{array}{l}\text { Maroon bush, currant } \\
\text { bush, prickly fan } \\
\text { flower }\end{array}$ & Stem, leaves & Leaves & $\begin{array}{l}\text { Antimicrobial (especially skin microbes/ } \\
\text { skin sores), pain, urinary disorders }\end{array}$ & {$[21,22,35]$} \\
\hline Syzygium anisatum & $\begin{array}{l}\text { Anise myrtle, aniseed } \\
\text { tree, Ringwood }\end{array}$ & Leaves & Leaves & $\begin{array}{l}\text { Antimicrobial (especially skin microbes/ } \\
\text { skin sores), high in essential oils, used for } \\
\text { food flavoring }\end{array}$ & [21] \\
\hline Syzygium austral & $\begin{array}{l}\text { Brush cherry, scrub } \\
\text { cherry }\end{array}$ & Leaves, fruit & Leaves, fruit & $\begin{array}{l}\text { High in antioxidants, antimicrobial } \\
\text { (especially skin microbes/skin sores), high } \\
\text { in essential oils, used for food flavoring }\end{array}$ & {$[21,27,30,32]$} \\
\hline Syzygium forte & White apple & Leaves, fruit & Leaves & $\begin{array}{l}\text { Antimicrobial (especially skin microbes/ } \\
\text { skin sores), high in essential oils }\end{array}$ & {$[21,27,31]$} \\
\hline Syzygium francisii & $\begin{array}{l}\text { Giant water gum, } \\
\text { rose satin ash }\end{array}$ & Leaves, fruit & Leaves & $\begin{array}{l}\text { Antimicrobial (especially skin microbes/ } \\
\text { skin sores), high in essential oils }\end{array}$ & {$[21,27,31]$} \\
\hline Syzygium moorei & Coolamon, durobby & Leaves, fruit & Leaves & $\begin{array}{l}\text { Antimicrobial (especially skin microbes/ } \\
\text { skin sores), high in essential oils }\end{array}$ & {$[21,27,31]$} \\
\hline Syzygium puberculum & Unknown & Leaves, fruit & Leaves & $\begin{array}{l}\text { Antimicrobial (especially skin microbes/ } \\
\text { skin sores), high in essential oils }\end{array}$ & {$[21,27,31]$} \\
\hline Syzygium wilsonii & $\begin{array}{l}\text { Water gum, plum } \\
\text { satin ash }\end{array}$ & Leaves, fruit & Leaves & $\begin{array}{l}\text { Antimicrobial (especially skin microbes/ } \\
\text { skin sores), high in essential oils }\end{array}$ & {$[21,27,31]$} \\
\hline Syzygium leuhmannii & $\begin{array}{l}\text { Riberry, cherry satin } \\
\text { ash }\end{array}$ & Leaves, fruit & Leaves, fruit & $\begin{array}{l}\text { High in antioxidants, antimicrobial } \\
\text { (especially skin microbes/skin sores), high } \\
\text { in essential oils, used for food flavoring }\end{array}$ & {$[21,27,30,32]$} \\
\hline Tasmannia insipida & Brush pepperbush & $\begin{array}{l}\text { Bark, leaves, } \\
\text { berries, } \\
\text { peppercorns }\end{array}$ & Leaves & $\begin{array}{l}\text { Used as a flavoring agent; medicinal uses } \\
\text { unknown-included due to its taxonomic } \\
\text { relationship to } T \text {. lanceolata }\end{array}$ & {$[21,65]$} \\
\hline Tasmannia lanceolata & $\begin{array}{l}\text { Mountain pepper, } \\
\text { pepperberry }\end{array}$ & $\begin{array}{l}\text { Bark, leaves, } \\
\text { berries, } \\
\text { peppercorns }\end{array}$ & $\begin{array}{l}\text { Leaves, } \\
\text { berries, } \\
\text { peppercorns }\end{array}$ & $\begin{array}{l}\text { Used as a flavoring agent; scurvy, } \\
\text { stomach disorders, antimicrobial, tonic, } \\
\text { skin disorders, STI's, quinine substitute }\end{array}$ & {$[21,24,65]$} \\
\hline Tasmannia stipitata & $\begin{array}{l}\text { Northern pepperbush, } \\
\text { Dorrigo pepper }\end{array}$ & $\begin{array}{l}\text { Bark, leaves, } \\
\text { berries, } \\
\text { peppercorns }\end{array}$ & $\begin{array}{l}\text { Leaves, } \\
\text { berries }\end{array}$ & $\begin{array}{l}\text { Used as a flavoring agent; medicinal uses } \\
\text { unknown-included due to its taxonomic } \\
\text { relationship to } T \text {. lanceolata }\end{array}$ & {$[21,65]$} \\
\hline
\end{tabular}

unable to find studies examining any anti-inflammatory properties of Aleurites moluccanus, $A$. excelsa, A. caerulea, and Duboisia leichbardtii despite their usage in traditional healing systems. ${ }^{[21,22]}$ As high levels of antioxidants have therapeutic effects against many diseases and medical conditions including inflammation and bacterial diseases, several high antioxidant plants were also included in this study. Tasmannia spp. and Sysygium spp. in particular, have been shown to have high antioxidant contents, ${ }^{[23]}$ as well as documented medicinal uses. ${ }^{[21,22]}$ Other species with high antioxidant contents (Davidsonia pruriens, Elaeocarpus angustifolius) were also included in the study despite a lack of documented ethnobotanical usage or reports of anti-inflammatory activity.

Several of the plant species identified as having anti-inflammatory properties have been studied previously for their antiseptic properties, although we were unable to find studies aimed at testing these plant species against RA. For example, recent studies have shown Tasmannia lanceolata to have potent inhibitory activity towards a wide range of bacteria. ${ }^{[24]}$ Similarly, Australian Acacia spp., ${ }^{[25]}$
Callistemon spp., ${ }^{[26,27]}$ Eucalyptus spp., ${ }^{[27,28]}$ Leptospermum spp., ${ }^{[2]}$ Melaleuca spp., ${ }^{[27]}$ Syzygium spp., ${ }^{[21,27,30-32]}$ P. angustifolia, ${ }^{[33]}$ and Petalostigma spp. ${ }^{[34]}$ have well-documented antibacterial activity against a wide variety of bacteria. Scaevola spinescens extracts have not only been shown to have broad-spectrum antimicrobial activity, ${ }^{[35]}$ but also have documented uses in the treatment of UTI's and urinary disorders. ${ }^{[21,22]}$

Several other plant species examined in this study are closely related taxonomically with species with known anti-inflammatory and antimicrobial activities. While we were unable to find reports of the ethnobotanical usage of Kunzea flavescens, extracts prepared from related Kunzea species are used in the treatment of rheumatism, swellings and inflammation. ${ }^{[1,22]}$ Other species examined in this study (e.g. T. insipidia and T. stipitata) have not been extensively studied for their anti-inflammatory or antimicrobial properties and are included in this study due to their taxonomic relationship with $T$. lanceolata. The selected plant species were extracted, and the extracts were tested against $P$. mirabilis to screen their potential to block the microbial triggers of RA. 


\section{MATERIALS AND METHODS}

\section{Ethnobotanical information}

Several literature resources [Table 1] were utilized to identify Australian native plants with a history of usage in the treatment of rheumatism and other inflammatory disorders.

\section{Plant collection and extraction}

The majority of the plant species tested in this study were collected from the Mt Cootha Botanical Gardens, Brisbane Australia. Of the other plants, Backhousia citriodora, B. myrtifolia, Elaeocarpus angustifolius, P. angustifolium, Sysygium anisatum, T. insipidia and T. stipitata were provided by individual members of the Qld Bushfoods Association, Australia. A. auriculiformis, A. diasparima, D. pruriens, $K$. flavescens, P. pubescens and P. triloculorae were collected from Griffith University, Australia. Macadamia integriflora, Callistemon citrinus, C. salignus, S. australae and S. leubmannii were collected from suburban gardens on the south side of Brisbane. T. lanceolata was supplied by Taste of Australia native food suppliers. $S$. spinescens was supplied by Jeanie Crago of outback Books. All plants were identified by Philip Cameron, senior botanical officer, the Brisbane Botanical Gardens. Voucher specimens were prepared and are stored at the School of Natural Sciences, Griffith University, Australia. All plant materials were air-dried in the shade and ground into a fine powder.

One gram of each dried plant material was weighed into each of two tubes for each plant. Extracts were prepared by adding $50 \mathrm{ml}$ of either AR grade methanol or distilled water to the tubes. Plant material was extracted in each solvent for $24 \mathrm{~h}$ at $4^{\circ} \mathrm{C}$ with gentle shaking. The extracts were filtered through filter paper (Whatman No. 54). The methanol extracts were subsequently allowed to dry at room temperature. The aqueous extracts were frozen at $-70^{\circ} \mathrm{C}$ and dried by lyophilization. The resultant dry extracts were weighed and redissolved in $10 \mathrm{ml}$ deionized water.

\section{Antibacterial screening}

\section{Test microorganisms}

A reference strain of $P$. mirabilis (American Tissue Culture Collection [ATCC] 43071) was obtained from ATCC. The bacteria were subcultured and maintained in nutrient broth at $4^{\circ} \mathrm{C}$.

\section{Evaluation of antimicrobial activity}

Antimicrobial activity of all plant extracts was determined using a modified disc diffusion method. ${ }^{[36,37]}$ Briefly, $100 \mu \mathrm{l}$ of the test bacteria were grown in $10 \mathrm{ml}$ of fresh nutrient broth until they reached a count of approximately $10^{8}$ cells/Ml. $100 \mu \mathrm{l}$ of microbial suspension was spread onto nutrient agar plates.
The extracts were tested using $5 \mathrm{~mm}$ sterilized filter paper discs. Discs were impregnated with $10 \mu \mathrm{l}$ of the test sample, allowed to dry and placed onto inoculated plates. The plates were allowed to stand at $4^{\circ} \mathrm{C}$ for $2 \mathrm{~h}$ before incubation with the test microbial agents. The plates were incubated at $30^{\circ} \mathrm{C}$ for $24 \mathrm{~h}$, then the diameters of the inhibition zones were measured in millimeters. All measurements were to the closest whole millimeter. Each antimicrobial assay was performed in at least triplicate, and mean values were determined. Standard discs of ampicillin $(2 \mu \mathrm{g})$ and chloramphenicol $(10 \mu \mathrm{g})$ were obtained from Oxoid Ltd. and served as positive controls for antimicrobial activity. Filter discs impregnated with $10 \mu \mathrm{l}$ of distilled water were used as negative controls.

\section{Minimum inhibitory concentration determination}

The minimum inhibitory concentrations (MICs) of the plant extracts were determined by the disc diffusion MIC method $^{[33,35]}$ across a range of doses. Briefly, the plant extracts were serially diluted in deionized water across a range of concentrations. Discs were impregnated with $10 \mu \mathrm{l}$ of the test dilutions, allowed to dry and placed onto inoculated plates. The assay was performed as outlined above, and graphs of the zone of inhibition versus concentration were plotted for each extract. Linear regression was used to calculate the MIC values.

\section{Toxicity screening}

\section{Reference toxin for biological screening}

Potassium dichromate $\left(\mathrm{K}_{2} \mathrm{Cr}_{2} \mathrm{O}_{7}\right.$ ) (AR grade, Chem-Supply, Australia) was prepared as a $1.6 \mathrm{mg} / \mathrm{ml}$ solution in distilled water and was serially diluted in synthetic seawater for use in the Artemia franciscana nauplii bioassay.

\section{Artemia franciscana nauplii toxicity screening}

Toxicity was tested using a modified $A$. franciscana nauplii lethality assay. ${ }^{[38-40]}$ Briefly, $A$. franciscana cysts were obtained from North American Brine Shrimp, LLC, USA (harvested from the Great Salt Lake, Utah). Synthetic seawater was prepared using Reef Salt, AZOO Co., USA. Seawater solutions at $34 \mathrm{~g} / \mathrm{L}$ distilled water were prepared prior to use. An amount of $2 \mathrm{~g}$ of $A$. franciscana cysts was incubated in 11 synthetic seawater under artificial light at $25^{\circ} \mathrm{C}, 2000$ Lux with continuous aeration. Hatching commenced within 16-18 h of incubation. Newly hatched A. franciscana (nauplii) were used within $10 \mathrm{~h}$ of hatching. Nauplii were separated from the shells and remaining cysts and were concentrated to a suitable density by placing an artificial light at one end of their incubation vessel and the nauplii rich water closest to the light was removed for biological assays. A volume of $400 \mu \mathrm{l}$ of seawater containing approximately 37 (mean $=37.2, n=132$, $\mathrm{SD}=11.6)$ nauplii was added to wells of a 48 well plate and immediately used for bioassay. The plant extracts were 
diluted to $4 \mathrm{mg} / \mathrm{ml}$ in seawater for toxicity testing, resulting in a $2 \mathrm{mg} / \mathrm{ml}$ concentration in the bioassay. A volume of $400 \mu \mathrm{l}$ of diluted plant extract and the reference toxin were transferred to the wells and incubated at $25 \pm 1^{\circ} \mathrm{C}$ under artificial light (1000 Lux). A negative control (400 $\mu$ l seawater) was run in at least triplicate for each plate. All treatments were performed in at least triplicate. The wells were checked at regular intervals, and the number of dead counted. The nauplii were considered moribund if no movement of the appendages was observed within $10 \mathrm{~s}$. Following the $24 \mathrm{~h}$ and exposure, all nauplii were sacrificed and counted to determine the total number per well. The $\mathrm{LC}_{50}$ with $95 \%$ confidence limits for each treatment was calculated using probit analysis.

High performance liquid chromatography-IMS/MS analysis

Chromatographic separations were performed using $10 \mu \mathrm{L}$ injections of sample onto an Agilent 1290 high performance liquid chromatography (HPLC) system fitted with a Zorbax Eclipse plus C18 column $(2.1 \times 100 \mathrm{~mm}$, $1.8 \mu \mathrm{m}$ particle size). The mobile phases consisted of (A) ultrapure water and (B) 95:5 acetonitrile/water at a flow rate of $0.7 \mathrm{~mL} / \mathrm{min}$. Both mobile phases were modified with $0.1 \%(\mathrm{v} / \mathrm{v})$ glacial acetic acid for mass spectrometry analysis in positive mode and with $5 \mathrm{mM}$ ammonium acetate for analysis in negative mode. The chromatographic conditions utilized for the study consisted of the first 5 min run isocratically at $5 \% \mathrm{~B}$, a gradient of (B) from $5 \%$ to $100 \%$ was applied from $5 \mathrm{~min}$ to $30 \mathrm{~min}$, followed by 3 min isocratically at $100 \%$. Mass spectrometry analysis was performed on an Agilent 6530 quadrupole time-of-flight spectrometer fitted with a Jetstream electrospray ionization source in both positive and negative mode.

Data were analyzed using the Masshunter Qualitative analysis software package (Agilent Technologies). Blanks using each of the solvent extraction systems were analyzed using the Find by Molecular Feature algorithm in the software package to generate a compound list of molecules with abundances $>10,000$ counts. This was then used as an exclusion list to eliminate background contaminant compounds from the analysis of the extracts. Each extract was then analyzed using the same parameters using the find by molecular feature function to generate a putative list of compounds in the extracts. Compound lists were then screened against three accurate mass databases; a database of known plant compounds of therapeutic importance generated specifically for this study (650 compounds); the Metlin metabolomics database (24,768 compounds); and the Forensic Toxicology Database by Agilent Technologies (7,509 compounds). Empirical formula for unidentified compounds was determined using the find formula function in the software package.

\section{Statistical analysis}

Data are expressed as the mean \pm standard error of the mean of at least three independent experiments.

\section{RESULTS}

\section{Liquid extraction yields}

Extraction of $1 \mathrm{~g}$ of the dried plant materials with methanol and water yielded dried plant extracts ranging from $19.9 \mathrm{mg}$ (P. pubescens leaf water extract) to $477 \mathrm{mg}$ (T. lanceolata peppercorn methanolic extract) [Table 2]. In general, methanol was more efficient at extracting material from the plant samples than water. Methanol extracted a greater amount of material for 45 of the 53 plant samples tested $(84.9 \%)$, whereas water extracted the greater amount of material for 6 of the 53 plant samples (11.3\%). Two samples extracted approximately equal masses in both water and methanol. A correlation was also noted between the plant part tested and the amount of extracted material. For 12 plant species (A. caerulea, C. citrinus, C. salignus, D. pruriens, Leptospermum bracteata, L. juniperium, M. integriflora, P. pubescens, P. trilocularae, S. australae, S. leubmannii and T. lanceolata), multiple plant materials were extracted. For those species where both leaf and flower were tested (C. citrinus, C. salignus, $L$. bracteata, $L$. juniperium), extraction of the leaf with either water or methanol generally resulted in higher yields of extracted material than from the flower extracts. Conversely, when both leaf and fruit extracts from the same plant were tested (A. caerulea, D. pruriens, M. integriflora, P. pubescens, $P$. triloculorae, $S$. australe, S. leuhmannii and T. lanceolata), extraction of the fruit with either solvent generally resulted in higher extraction yields than the corresponding leaf extracts. $S$. australe extracts were the exception to this trend, with both methanol and water extracting greater masses from the leaves than from the fruit. The dried extracts were resuspended in $10 \mathrm{ml}$ of deionized water resulting in the extract concentrations shown in Table 2.

\section{Antibacterial activity}

As decoctions and tinctures are the main forms in which plants were traditionally used in ethnobotanical medicinal systems, the zones of inhibition of the methanolic and aqueous extracts were tested undiluted to provide an approximate measure of the efficacy of the form in which the traditional medications would be used. Aliquots $(10 \mu \mathrm{l})$ of each extract were screened against $P$. mirabilis [Figure 2]. P. mirabilis was inhibited by 65 of the $106(61.3 \%)$ extracts tested. Similar numbers of methanolic (33 of 53 methanolic extracts; $62.3 \%$ ) and aqueous extracts (32 of 53 aqueous extracts; 60.4\%) inhibited P. mirabilis growth.

The most effective inhibitors of P. mirabilis growth were the T. lanceolata and Datura leichardtii extracts based on 


\begin{tabular}{|c|c|c|c|c|c|}
\hline & Species/Extract & $\mu \mathrm{g}$ & $\mu \mathrm{g} / \mathrm{ml}$ & MIC $(\mu \mathrm{g} / \mathrm{ml})$ & $\mathrm{LC}_{50}(\mu \mathrm{g} / \mathrm{ml})$ \\
\hline $1 \mathrm{M}$ & Acacia auriculiformis (L M) & 150 & 15 & 1318.7 & - \\
\hline $1 \mathrm{~W}$ & Acacia auriculiformis ( $\mathrm{L}$ W) & 67 & 6.7 & 1893.6 & - \\
\hline $2 \mathrm{M}$ & Acacia diasparima (L M) & 140 & 14 & 2587.6 & - \\
\hline $2 \mathrm{~W}$ & Acacia diasparima (L W) & 85 & 8.5 & 3361.9 & - \\
\hline $3 \mathrm{M}$ & Acacia leptoloba (L M) & 83 & 8.3 & 4369.7 & - \\
\hline $3 \mathrm{~W}$ & Acacia leptoloba (L W) & 56 & 5.6 & 4663.9 & - \\
\hline $4 \mathrm{M}$ & Aleurites moluccanus (N M) & 192 & 19.2 & 243 & - \\
\hline $4 \mathrm{~W}$ & Aleurites moluccanus ( $\mathrm{N} \mathrm{W}$ ) & 200 & 20 & 270 & - \\
\hline $5 \mathrm{M}$ & Alphitonia excelsa (L M) & 108 & 10.8 & - & - \\
\hline $5 \mathrm{~W}$ & Alphitonia excelsa (L W) & 73 & 7.3 & - & - \\
\hline $6 \mathrm{M}$ & Alpinia caerulea (F M) & 88 & 8.8 & 4337.7 & - \\
\hline $6 \mathrm{~W}$ & Alpinia caerulea (F W) & 72 & 7.2 & 5881.5 & - \\
\hline $7 \mathrm{M}$ & Alpinia caerulea (L M) & 116 & 11.6 & 735.9 & - \\
\hline $7 \mathrm{~W}$ & Alpinia caerulea (L W) & 73 & 7.3 & 1284.2 & - \\
\hline $8 M$ & Backhousia citriodora (L M) & 154 & 15.4 & 425 & - \\
\hline $8 \mathrm{~W}$ & Backhousia citriodora ( L W) & 65 & 6.5 & 2230 & - \\
\hline $9 \mathrm{M}$ & Backhousia myrtiflora (L M) & 253 & 25.3 & 3150 & - \\
\hline $9 \mathrm{~W}$ & Backhousia myrtiflora (L W) & 178 & 17.8 & 3378 & - \\
\hline $10 \mathrm{M}$ & Callistemon citrinus (L M) & 340 & 34 & 1558.9 & - \\
\hline $10 \mathrm{~W}$ & Callistemon citrinus (L W) & 260 & 26 & 2146.3 & - \\
\hline $11 \mathrm{M}$ & Callistemon citrinus (FI M) & 370 & 37 & 1767.8 & - \\
\hline $11 \mathrm{~W}$ & Callistemon citrinus (FI W) & 240 & 24 & 2005.5 & - \\
\hline $12 \mathrm{M}$ & Callistemon formosus (L M) & 285 & 28.5 & 1400.6 & - \\
\hline $12 \mathrm{~W}$ & Callistemon formosus (L W) & 228 & 22.8 & 1670 & - \\
\hline $13 \mathrm{M}$ & Callistemon salignus ( $\mathrm{L} \mathrm{M})$ & 320 & 32 & 2187.8 & - \\
\hline $13 \mathrm{~W}$ & Callistemon salignus (L W) & 270 & 27 & 2576.3 & - \\
\hline $14 \mathrm{M}$ & Callistemon salignus (FI M) & 295 & 29.5 & 2487.9 & - \\
\hline $14 \mathrm{~W}$ & Callistemon salignus (FI W) & 243 & 24.3 & 2778 & - \\
\hline $15 \mathrm{M}$ & Cinnamomum oliveri (L M) & 215 & 21.5 & 687.9 & 6760 \\
\hline $15 \mathrm{~W}$ & Cinnamomum oliveri (L W) & 60 & 6 & 1463.1 & - \\
\hline $16 \mathrm{M}$ & Davidsonia pruriens (L M) & 134 & 13.4 & - & - \\
\hline $16 \mathrm{~W}$ & Davidsonia pruriens (L W) & 43 & 4.3 & - & - \\
\hline $17 \mathrm{M}$ & Davidsonia pruriens (F M) & 188 & 18.8 & 1725.6 & 6443 \\
\hline $17 \mathrm{~W}$ & Davidsonia pruriens (F W) & 104 & 10.4 & 2238.9 & 2883.3 \\
\hline $18 \mathrm{M}$ & Duboisia leichhardtii (L M) & 184 & 18.4 & 588.5 & - \\
\hline $18 \mathrm{~W}$ & Duboisia leichhardtii (L W) & 112 & 11.2 & 1267.2 & - \\
\hline $19 M$ & Elaeocarpus angustifolius (F M) & 34 & 3.4 & - & 8783 \\
\hline $19 \mathrm{~W}$ & Elaeocarpus angustifolius (F W) & 146 & 14.6 & - & 7699 \\
\hline $20 \mathrm{M}$ & Eucalyptus baileyana (L M) & 218 & 21.8 & 847.3 & 216.7 \\
\hline $20 \mathrm{~W}$ & Eucalyptus baileyana (L W) & 144.8 & 14.5 & 1145.8 & 783.7 \\
\hline $21 \mathrm{M}$ & Eucalyptus major (L M) & 427.3 & 42.7 & 449.5 & 662.9 \\
\hline $21 \mathrm{~W}$ & Eucalyptus major (L W) & 165.5 & 16.6 & 873.7 & 896.3 \\
\hline $22 \mathrm{M}$ & Kunzea flavescens ( $L \mathrm{M})$ & 312.4 & 31.2 & - & - \\
\hline $22 \mathrm{~W}$ & Kunzea flavescens ( $\mathrm{L}$ W) & 177.7 & 17.8 & - & - \\
\hline $23 \mathrm{M}$ & Leptospermum bracteata (L M) & 208 & 20.8 & 387.8 & - \\
\hline $23 \mathrm{~W}$ & Leptospermum bracteata (L W) & 140 & 14 & 742 & - \\
\hline $24 \mathrm{M}$ & Leptospermum bracteata (FI M) & 178 & 17.8 & 653.7 & - \\
\hline $24 \mathrm{~W}$ & Leptospermum bracteata (FI W) & 115 & 11.5 & 1172.5 & - \\
\hline $25 \mathrm{M}$ & Leptospermum juniperium (L M) & 184 & 18.4 & 484.3 & - \\
\hline $25 W$ & Leptospermum juniperium (L W) & 131 & 131 & 876.3 & - \\
\hline $26 \mathrm{M}$ & Leptospermum juniperium (FI M) & 122 & 12.2 & 844.9 & - \\
\hline $26 \mathrm{~W}$ & Leptospermum juniperium (FI W) & 97 & 9.7 & 1367.5 & - \\
\hline $27 \mathrm{M}$ & Leptospermum Iongifolium (L M) & 259 & 25.9 & 1454.3 & - \\
\hline $27 \mathrm{~W}$ & Leptospermum longifolium ( $\mathrm{L}$ W) & 118 & 11.8 & 1663.8 & - \\
\hline
\end{tabular}

Contd.. 


\begin{tabular}{|c|c|c|c|c|c|}
\hline & Species/Extract & $\mu \mathrm{g}$ & $\mu \mathrm{g} / \mathrm{ml}$ & MIC $(\mu \mathrm{g} / \mathrm{ml})$ & $\mathrm{LC}_{50}(\mu \mathrm{g} / \mathrm{ml})$ \\
\hline $28 \mathrm{M}$ & Leptospermum petersonii (L M) & 233 & 23.3 & 1499 & 2467 \\
\hline $28 \mathrm{~W}$ & Leptospermum petersonii (L W) & 145 & 14.5 & 1887.2 & 3221 \\
\hline $29 M$ & Macadamia integriflora (N M) & 382.5 & 38.3 & 15 & - \\
\hline $29 \mathrm{~W}$ & Macadamia integriflora ( $\mathrm{N} \mathrm{W}$ ) & 199.1 & 19.9 & 558 & - \\
\hline $30 \mathrm{M}$ & Macadamia integriflora (L M) & 75 & 7.5 & 2790 & - \\
\hline $30 \mathrm{~W}$ & Macadamia integriflora (L W) & 102.7 & 10.3 & 4378.2 & - \\
\hline $31 \mathrm{M}$ & Melaleuca alternifolia (L M) & 185 & 18.5 & 684.9 & - \\
\hline $31 \mathrm{~W}$ & Melaleuca alternifolia (L W) & 120 & 12 & 983.1 & - \\
\hline $32 \mathrm{M}$ & Melaleuca quinquenervia (L M) & 134 & 13.4 & 435.2 & - \\
\hline $32 \mathrm{~W}$ & Melaleuca quinquenervia (L W) & 87 & 8.7 & 673.8 & - \\
\hline $33 \mathrm{M}$ & Petalostigma pubescens (L M) & 90 & 9 & 287 & - \\
\hline $33 \mathrm{~W}$ & Petalostigma pubescens (L W) & 19.9 & 2 & 1427 & - \\
\hline $34 \mathrm{M}$ & Petalostigma pubescens (F M) & 154 & 15.4 & 458.6 & - \\
\hline $34 \mathrm{~W}$ & Petalostigma pubescens (F W) & 65 & 6.5 & 783.9 & - \\
\hline $35 \mathrm{M}$ & Petalostigma triloculorae (L M) & 123 & 12.3 & 320.7 & - \\
\hline $35 \mathrm{~W}$ & Petalostigma triloculorae (L W) & 111 & 11.1 & 1126.5 & - \\
\hline $36 \mathrm{M}$ & Petalostigma triloculorae (F M) & 273 & 27.3 & 412.7 & - \\
\hline $36 \mathrm{~W}$ & Petalostigma triloculorae (F W) & 87 & 8.7 & 378.6 & - \\
\hline $37 \mathrm{M}$ & Pittosporum augustifolium (L M) & 64 & 6.4 & 473.4 & - \\
\hline $37 \mathrm{~W}$ & Pittosporum augustifolium (L W) & 111 & 11.1 & 770.4 & - \\
\hline $38 \mathrm{M}$ & Scaevola spinescens (L M) & 116 & 11.6 & 151.9 & - \\
\hline $38 \mathrm{~W}$ & Scaevola spinescens (L W) & 210 & 21 & 25.4 & - \\
\hline $39 M$ & Syzygium anisatum (L M) & 90 & 9 & 1315.2 & - \\
\hline $39 \mathrm{~W}$ & Syzygium anisatum ( $\mathrm{L} \mathrm{W})$ & 87 & 8.7 & - & - \\
\hline $40 \mathrm{M}$ & Syzygium australe (L M) & 270 & 27 & 976.3 & 1879.3 \\
\hline $40 \mathrm{~W}$ & Syzygium australe (L W) & 140 & 14 & 1328.4 & 3310 \\
\hline $41 \mathrm{M}$ & Syzygium australe (F M) & 254 & 25.4 & 769 & 294 \\
\hline $41 \mathrm{~W}$ & Syzygium australe (F W) & 200 & 20 & 636.9 & 244 \\
\hline $42 \mathrm{M}$ & Syzygium forte (L M) & 54 & 5.4 & - & 392 \\
\hline $42 W$ & Syzygium forte (L W) & 32 & 3.2 & - & 762 \\
\hline $43 \mathrm{M}$ & Syzygium francisii (L M) & 156 & 15.6 & - & - \\
\hline $43 \mathrm{~W}$ & Syzygium francisii (L W) & 128 & 12.8 & - & - \\
\hline $44 \mathrm{M}$ & Syzygium moorei (L M) & 132 & 13.2 & - & 1312 \\
\hline $44 \mathrm{~W}$ & Syzygium moorei (L W) & 84 & 8.4 & - & 1687 \\
\hline $45 \mathrm{M}$ & Syzygium puberculum (L M) & 317 & 31.7 & - & - \\
\hline $45 W$ & Syzygium puberculum (L W) & 117 & 11.7 & - & - \\
\hline $46 \mathrm{M}$ & Syzygium wilsonii (L M) & 108 & 10.8 & - & - \\
\hline $46 \mathrm{~W}$ & Syzygium wilsonii (L W) & 43 & 4.3 & - & - \\
\hline $47 \mathrm{M}$ & Syzygium leuhmannii (L M) & 180 & 18 & - & 449.8 \\
\hline $47 \mathrm{~W}$ & Syzygium leuhmannii (L W) & 75 & 7.5 & - & 813.1 \\
\hline $48 \mathrm{M}$ & Syzygium leuhmannii (F M) & 427 & 42.7 & 2900 & 414 \\
\hline $48 \mathrm{~W}$ & Syzygium leuhmannii (F W) & 442 & 44.2 & 4700 & 478 \\
\hline $49 M$ & Tasmannia insipida (L M) & 118 & 11.8 & 891.4 & 3228.9 \\
\hline $49 W$ & Tasmannia insipida (L W) & 103.9 & 10.4 & 1252.6 & 4732.1 \\
\hline $50 \mathrm{M}$ & Tasmannia lanceolata (L M) & 144 & 14.4 & 643 & 3096 \\
\hline $50 \mathrm{~W}$ & Tasmannia lanceolata (L W) & 134 & 13.4 & 56 & 2665 \\
\hline $51 \mathrm{M}$ & Tasmannia lanceolata (F M) & 171 & 17.1 & 11 & 3573 \\
\hline $51 \mathrm{~W}$ & Tasmannia lanceolata (F W) & 111 & 11.1 & 126 & 2376 \\
\hline $52 \mathrm{M}$ & Tasmannia lanceolata (P M) & 295 & 29.5 & 89 & 4159 \\
\hline $52 \mathrm{~W}$ & Tasmannia lanceolata (P W) & 477 & 47.7 & 414 & 3029 \\
\hline $53 \mathrm{M}$ & Tasmannia stipitata (L M) & 126.4 & 12.6 & 268.3 & 2878.4 \\
\hline \multirow[t]{2}{*}{$53 \mathrm{~W}$} & Tasmannia stipitata (L W) & 87.6 & 8.8 & 744.5 & 4641 \\
\hline & Potassium dichromate & & & & 92.3 \\
\hline
\end{tabular}

Numbers indicate the mean MIC or LC 50 values of at least triplicate determinations. -: No growth inhibition or mortality; L: Leaf; F: Fruit; FI: Flower; N: Nut; M: Methanolic extract; W: Water extract; MIC: Minimum inhibitory concentrations; P. mirabilis: Proteus mirabilis 


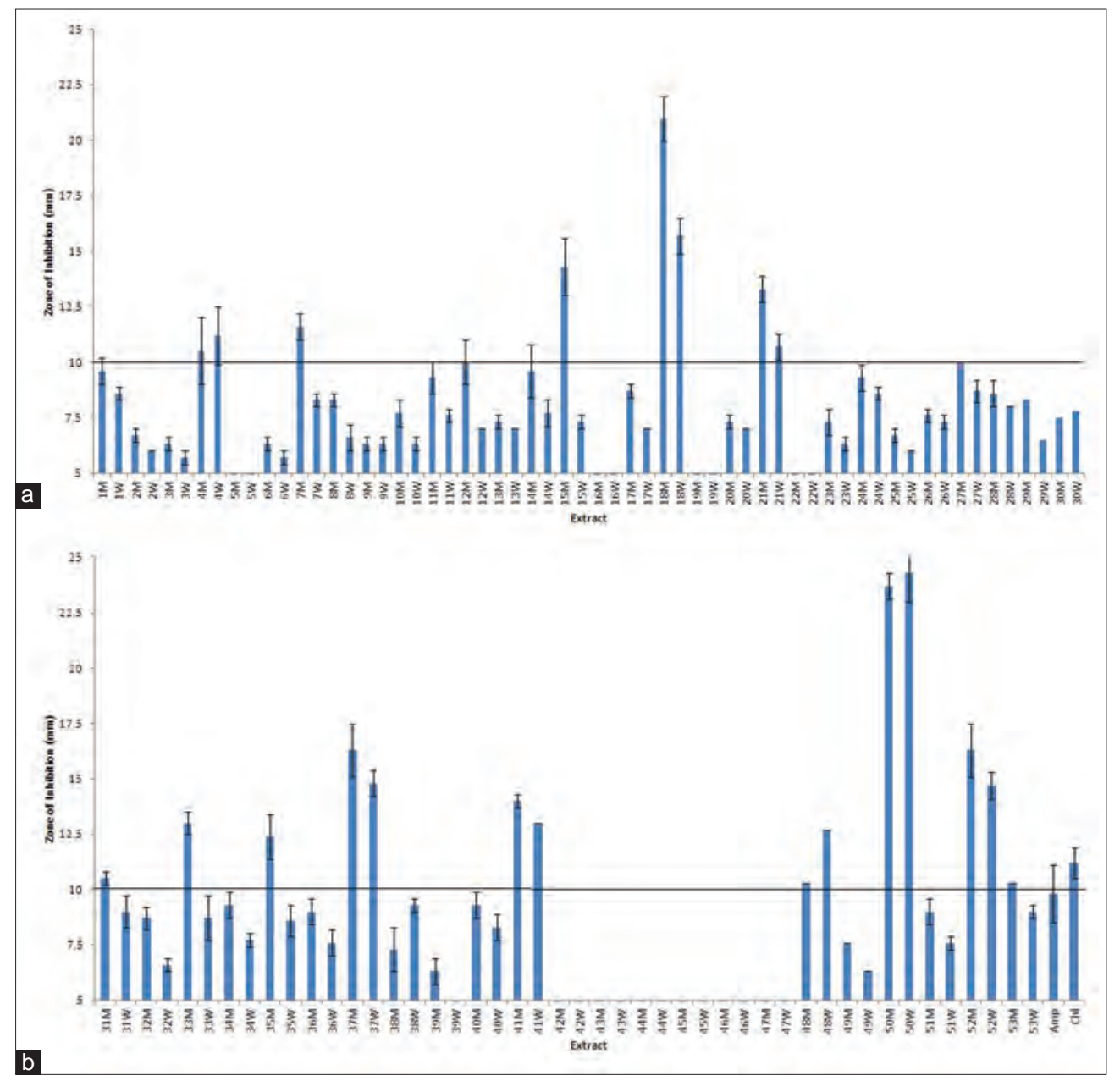

Figure 2: Antibacterial activity of plant water and methanolic extracts measured as zones of inhibition (mm) against Proteus mirabilis. Inhibition zones are represented as the means of at least triplicate experiments \pm standard error of the mean. $\mathrm{M}$ and $\mathrm{W}$ refer to methanolic and water extracts respectively. (a) $1=A$. auriculiformis leaf; $2=A$. diasparima leaf; $3=A$. leptoloba leaf; $4=A$. moluccanus nut; $5=A$. excelsa leaf; $6=$ A. caerulea fruit; $7=A$. caerulea leaf; $8=B$. citriodora leaf; $9=B$. myrtiflora leaf; $10=$ Callistemon citrinus leaf; $11=$ C. citrinus flower, $12=$ C. formosus leaf; $13=$ C. salignus leaf; $14=$ C. salignus flower; $15=C$. oliveri leaf; $16=$ Davidsonia pruriens leaf; $17=D$. pruriens fruit; $18=$ D. leichhardtii leaf; $19=$ Elaeocarpus angustifolius fruit; $20=E$. baileyana leaf; $21=E$. major leaf; $22=$ Kunzea flavescens leaf; $23=$ Leptospermum bracteata leaf; $24=$ L. bracteata flower; $25=$ L. juniperium leaf; $26=$ L. juniperium flower; $27=L$. longifolium leaf; $28=L$. petersoni leaf; $29=$ Macadamia integriflora nut; $30=$ M. integriflora leaf; (b) $31=$ M. alternifolia leaf; $32=$ M. quinquenervia leaf; $33=$ Petalostigma

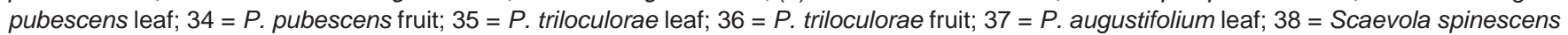
leaf; $39=$ Syzygium anisatum leaf; $40=$ S. australe leaf; $41=$ S. australe fruit; $42=$ S. forte leaf; $43=S$. francisii leaf; $44=S$. moorei leaf; $45=$ S. puberculum leaf; $46=$ S. wilsonii leaf; $47=S$. leuhmannii leaf; $48=S$. leuhmannii fruit; $49=$ Tasmannia insipida leaf; $50=T$. lanceolata leaf; $51=T$. lanceolata fruit; $52=T$. lanceolata peppercorn; $53=T$. stipitata leaf; Amp = Ampicillin control $(2 \mu \mathrm{g}) ; \mathrm{Chl}=\mathrm{Chloramphenicol} \mathrm{control}(10 \mu \mathrm{g})$

the zones of inhibition $(24.4 \mathrm{~mm}$ for the T. lanceolata leaf methanolic extract). Indeed, these extracts displayed substantially more potent $P$. mirabilis growth inhibition than either of the control antibiotics (ampicillin and chloramphenicol). The A. moluccanus nut, A. caerulea leaf, C. formosus leaf, C. oliveri, Eucalyptus major, L. longifolium, $M$. alternofolia, P. pubescens leaf, P. triloculare leaf, $P$. augustifolium, $S$. australe fruit, $S$. leubmannii fruit, and T. stipitata leaf extracts also displayed strong P. mirabilis growth inhibition, with zones of inhibition $>10 \mathrm{~mm}$ and thus were also considered promising anti-P. mirabilis extracts.
The relative level of antibacterial activity was further quantified by determining the MIC values for each extract [Table 2]. The A. moluccanus, D. leichardtii, E. major, L. bracteata, L. juniperium, M. integriflora nut, $M$. alternifolia, M. quinquenervia, P. pubescens, $P$. triloculorae, P. augustifolium, S. spinescens, S. australe, and T. lanceolata extracts were determined to be the most effective inhibitors of $P$. mirabilis growth, with MIC values generally significantly below $1000 \mu \mathrm{g} / \mathrm{ml}$. T. lanceolata fruit extracts were the most potent growth inhibitors, with MICs of 11 and $126 \mu \mathrm{g} / \mathrm{ml}$ for the methanolic and aqueous extracts, respectively. Furthermore, noteworthy was the low MIC values seen for $M$. integriflora nut methanolic extract $(15 \mu \mathrm{g} / \mathrm{ml})$ and the $S$. spinescens leaf water extract $(25.4 \mu \mathrm{g} / \mathrm{ml})$. 


\section{Quantification of toxicity}

The plant extracts were serially diluted in artificial seawater for toxicity testing in the Artemia nauplii lethality bioassay. For comparison, the reference toxin potassium dichromate was also tested in the bioassay. Figure 3 shows the percentage mortality induced in the Artemia nauplii following 24 of exposure. Potassium dichromate (reference toxin) was rapid in its induction of mortality, inducing the onset of mortality within the first $3 \mathrm{~h}$ of exposure (results not shown). By $24 \mathrm{~h}$ of exposure, potassium dichromate had induced 100\% mortality in the Artemia nauplii. At $24 \mathrm{~h}$, several extracts induced mortality significantly above that of the seawater control. The E. baileyana methanol extract, $S$. australe leaf and fruit methanol and water extracts, S. leubmannii leaf and fruit methanol and water extracts and all extracts of Tasmannia spp. induced $100 \%$ mortality at $24 \mathrm{~h}$. While appearing less toxic, C. oliveri methanol extract, both $D$. pruriens fruit extracts, both E. angustifolius extracts, E. major methanolic extract and both $S$. forte extracts all induced significant $(>50 \%)$ mortality in the Artemia nauplii bioassay. The levels of mortality for all other extracts following $24 \mathrm{~h}$ and exposure was below 50\% and thus these extracts were considered nontoxic.

To benchmark the toxicity of the extracts that induced significant mortality for comparison with other toxins, the $\mathrm{LC}_{50}$ values of the extracts was determined by testing

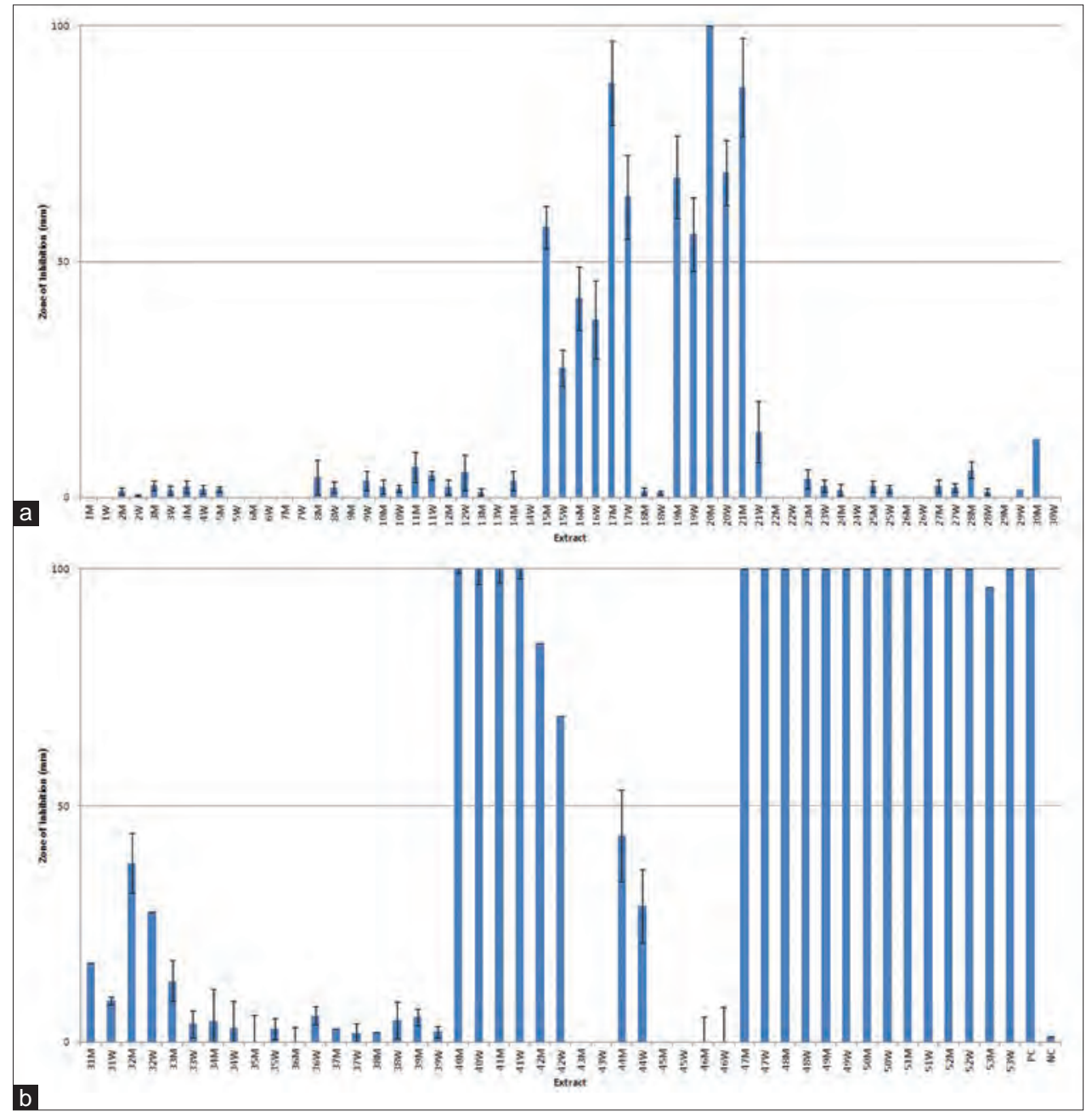

Figure 3: The lethality of Australian plant extracts $(2000 \mu \mathrm{g} / \mathrm{ml})$ towards Artemia franciscana nauplii after 24 hours exposure. Results are expressed as mean \pm SEM of at least triplicate determinations. $\mathrm{M}$ and $\mathrm{W}$ refer to methanolic and water extracts respectively. (a) $1=\mathrm{Acacia}$ auriculiformis leaf; $2=A$. diasparima leaf; $3=A$. leptoloba leaf; $4=A$. moluccanus nut; $5=A$. excelsa leaf; $6=A$. caerulea fruit; $7=A$. caerulea leaf; $8=$ Backhousia citriodora leaf; $9=$ B. myrtiflora leaf; $10=$ C. citrinus leaf; $11=$ Callistemon citrinus flower; $12=C$. formosus leaf; $13=C$. salignus leaf; $14=$ C. salignus flower; $15=$ C. oliveri leaf; $16=$ Davidsonia pruriens leaf; $17=D$. pruriens fruit; $18=D$. leichhardtii leaf; $19=E$ laeocarpus angustifolius fruit; $20=E$. baileyana leaf; $21=E$. major leaf; $22=$ Kunzea flavescens leaf; $23=$ Leptospermum bracteata leaf; $24=L$. bracteata flower; $25=$ L. juniperium leaf; $26=$ L. juniperium flower; $27=$ L. longifolium leaf; $28=$ L. petersoni leaf; $29=$ Macadamia integriflora nut; $30=M$. integriflora leaf; (b) $31=M$. alternifolia leaf; $32=M$. quinquenervia leaf; $33=$ Petalostigma pubescens leaf; $34=P$. pubescens fruit; $35=P$. triloculorae leaf; $36=P$. triloculorae fruit; $37=P$. augustifolium leaf; $38=$ Scaevola spinescens leaf; $39=$ Syzygium anisatum leaf; $40=S$. australe leaf; $41=S$. australe fruit; $42=S$. forte leaf; $43=S$. francisii leaf; $44=$ S. moorei leaf; $45=S$. puberculum leaf; $46=S$. wilsonii leaf; $47=S$. leuhmannii leaf; 48 = S. leuhmanni fruit; $49=$ Tasmannia insipida leaf; $50=T$. lanceolata leaf; $51=T$. lanceolata fruit; $52=T$. lanceolata peppercorn; $53=T$. stipitata leaf. PC = Potassium dichromate positive control $(1000 \mu \mathrm{g} / \mathrm{ml}) ; \mathrm{NC}=$ seawater negative control 
across the concentration range $2000 \mu \mathrm{g} / \mathrm{ml}$ to $125 \mu \mathrm{g} / \mathrm{ml}$ in the Artemia nauplii bioassay. For comparison, potassium dichromate was tested across the same concentration range. Table 2 shows the $\mathrm{LC}_{50}$ values of the extracts which had shown toxicity toward $A$. franciscana. While several extracts appeared toxic in the extract mortality screening study [Figure 3], determination of their $\mathrm{LC}_{50}$ values demonstrates that most were nontoxic as $\mathrm{LC}_{50}$ values of $\geq 1000 \mu \mathrm{g} / \mathrm{ml}$ have previously been defined as nontoxic in the Artemia nauplii bioassay. ${ }^{[4]}$ While the $C$. oliverimethanol extract, both $D$. pruriens fruit extracts, both E. angustifolius extracts, $S$. australe leaf extracts and all Tasmannia spp. extracts appeared toxic in the screening study [Figure 3], all had $\mathrm{LC}_{50}$ values of $\geq 1000 \mu \mathrm{g} / \mathrm{ml}$ and are therefore considered to be nontoxic. In contrast, all Eucalyptus spp. extracts, the $S$. australe fruit extracts and all $S$. forte and S. leubmannii extracts had $\mathrm{LC}_{50}$ values $\leq 1000 \mu \mathrm{g} / \mathrm{ml}$ and were therefore considered to be toxic. While these extracts displayed significant toxicity, potassium dichromate (the positive control) displayed substantially higher toxicity at $24 \mathrm{~h}\left(24 \mathrm{~h} \mathrm{LC}_{50} 92.3 \mu \mathrm{g} / \mathrm{ml}\right)$.

High performance liquid chromatography-MS/MS analysis of extracts displaying antimicrobial activity

The Proteus growth inhibition and MIC studies indicated that $T$. lanceolata fruit extracts had the most promise for further phytochemical characterization.
These were examined for the presence of the trans-3,4,5-trihydroxy-trans-stilbene (resveratrol) to examine whether resveratrol may be responsible for the anti-Proteus activity observed in these studies. Resveratrol is a potent anti-inflammatory compound produced as a phytoalexin (plant antibiotic) by many diverse plant species including grapes, berries, peanuts ${ }^{[42]}$ as well as some species of pine trees, Acacias, Terminalias, ${ }^{[43]}$ orchids, and lilies (Polunin et al., 2002). ${ }^{[4]}$

Optimized HPLC-MS/MS parameters were developed and used to profile the compounds from the methanolic [Figure 4] and aqueous [Figure 5] extractions of T. lanceolata fruit. Although the negative ion chromatograms yielded significantly higher signals than those observed for the positive ion (an order of magnitude higher), the negative ion chromatogram had significantly higher background levels, due to ionization of the reference ions in this mode. The T. lanceolata fruit methanol extract chromatograms in both positive and negative ion modes [Figure 4] revealed numerous overlapping peaks, particularly in the early and middle stages of the chromatogram corresponding to the elution of polar compounds. Nearly, all of the methanol extract compounds had eluted by $12 \mathrm{~min}$ (corresponding to approximately $27 \%$ acetonitrile). Indeed, numerous peaks eluted in the first 5 min with $5 \%$ acetonitrile. However, a prominent peak
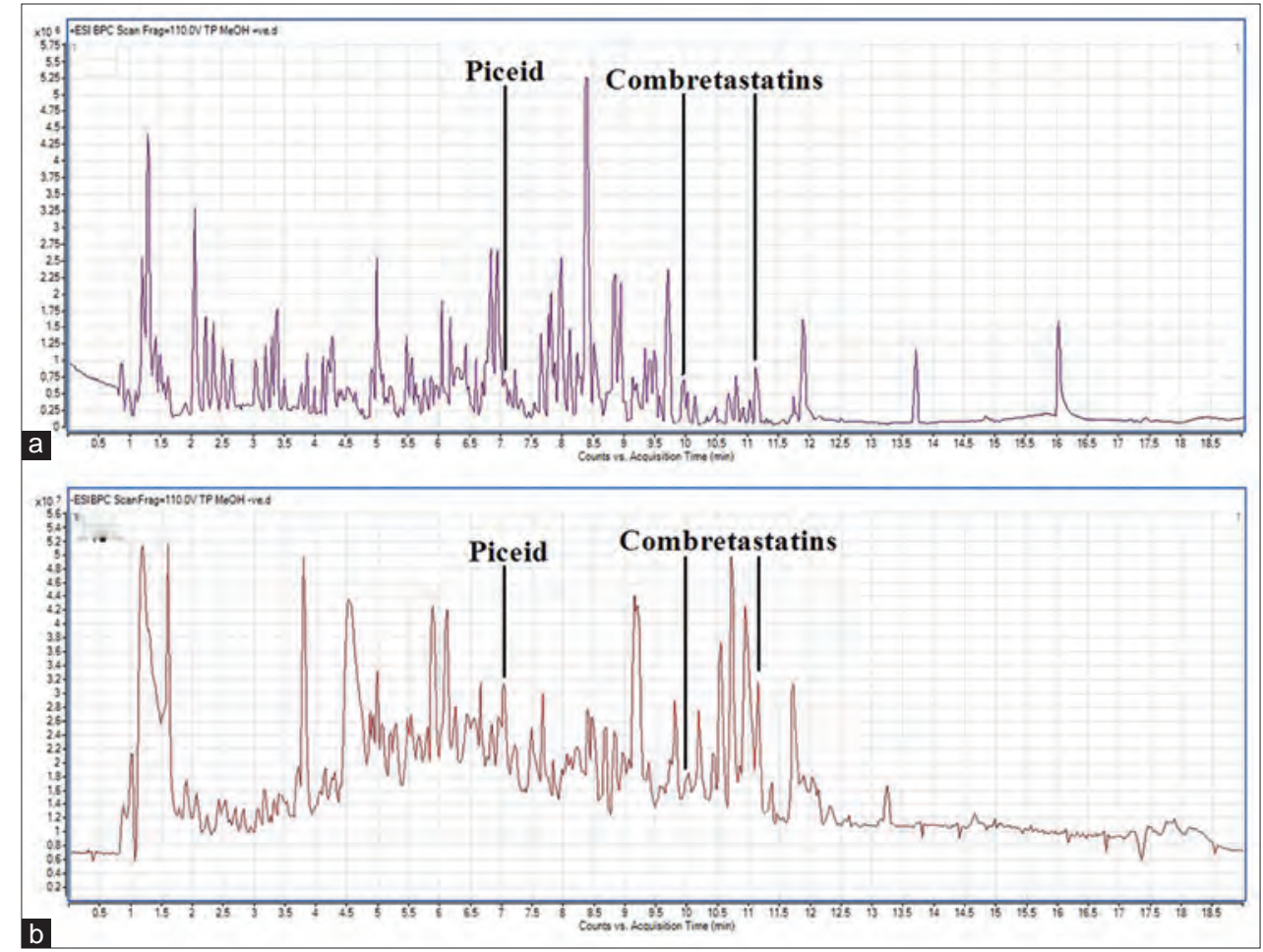

Figure 4: Reversed-phase high performance liquid chromatography total peak chromatogram of $10 \mu$ injections of the methanolic extracts of Tasmannia lanceolata fruit (a) in positive ionisation mode and (b) in negative ionisation mode. Extracts were dried and resuspended in deionised water. Arrows indicate the stilbene peaks detected in each chromatogram. Chromatography conditions were as described in the methods section 


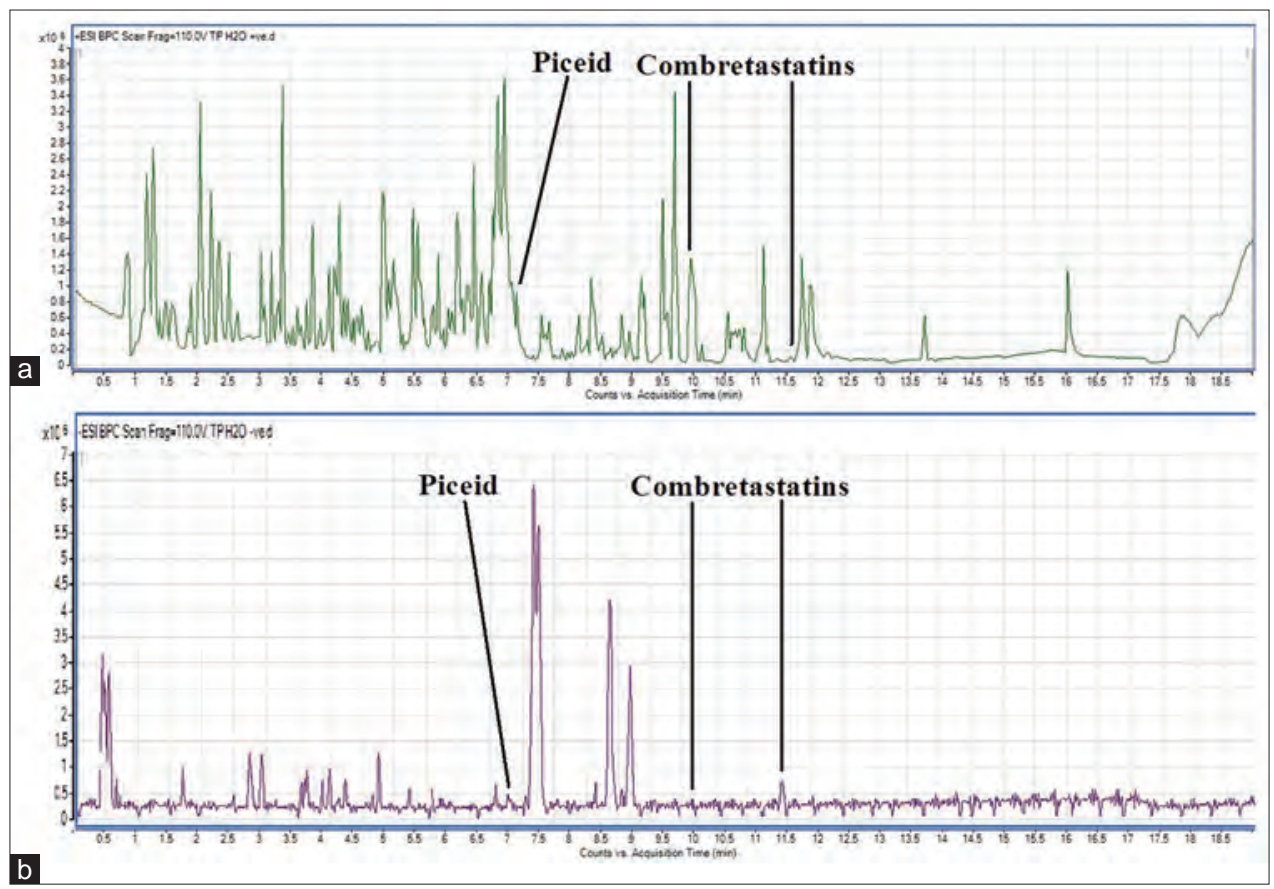

Figure 5: Reversed-phase high performance liquid chromatography total peak chromatogram of $10 \mu$ injections of the aqueous extracts of Tasmannia lanceolata fruit (a) in positive ionisation mode and (b) in negative ionisation mode. Extracts were dried and resuspended in deionised water. Arrows indicate the stilbene peaks detected in each chromatogram. Chromatography conditions were as described in the methods section

eluting later in the positive ion chromatogram [Figure 4a] at approximately $16 \mathrm{~min}$ (corresponding to approximately $44 \%$ acetonitrile) indicates the broad spread of polarities of the compounds in this extract. This later eluting peak was not apparent in the T. lanceolata fruit methanol extract negative ion chromatogram [Figure 4b].

The T. lanceolata fruit water extract chromatograms [Figure 5] also showed large amounts of polar material eluting early in the chromatogram at similar elution volumes as many of the compounds in the methanol extract. The aqueous extracts also had many of the same later eluting peaks seen in the methanolic extracts, including the peak at approximately $16 \mathrm{~min}$. Interestingly, none of the extracts tested displayed peaks corresponding to the molecular mass signal/empirical formula of a pure resveratrol standard in either positive or negative ionisation mode. However, both the methanolic and aqueous T. lanceolata fruit extracts displayed small peaks, with molecular weights consistent with picied and combretastatins A-1 and A-4, indicating the presence of only low levels of stilbenes in these extracts. A comparison with the accurate mass databases putatively identified these compounds as Piceid (molecular weight 404.1465 Da), combretastatin A-1 (molecular weight $332.1319 \mathrm{Da}$ ) and combretastatin A-4 (molecular weight $316.1287 \mathrm{Da}$ ).

An examination of the fragmentation ions in positive mode provided further evidence of the putative identity of these stilbenes in the T. lanceolata fruit extracts [Table 3].
Fragmentation of the compound identified as Piceid (identified by comparison to molecular mass databases) yielded peaks corresponding to the molecular ion mass $(404.1465 \mathrm{Da})$ as well as fragments corresponding to 286.1453, 270.0472, 228.1447, 124.1348, and 108.1212 Da. The empirical formulae corresponding to these fragments were determined using the Find by Molecular Feature algorithm in the Masshunter Qualitative analysis software package (Agilent Technologies). The molecular formulae $\mathrm{C}_{13} \mathrm{H}_{18} \mathrm{O}_{7}, \mathrm{C}_{6} \mathrm{H}_{12} \mathrm{O}_{6}, \mathrm{C}_{14} \mathrm{H}_{12} \mathrm{O}_{3}, \mathrm{C}_{7} \mathrm{H}_{8} \mathrm{O}_{2}$, and $\mathrm{C}_{7} \mathrm{H}_{8} \mathrm{O}$ were assigned for the fragments, respectively. Comparison with the molecular mass databases indicated the putative structures of these fragments [Figure 6]. It is likely that fragments b1 and b5 arise from a cleavage of the glucose moiety from the resveratrol moiety of Piceid. Thus, these fragments were putatively identified as resveratrol (228.1447 $\left.\mathrm{Da}, \mathrm{C}_{14} \mathrm{H}_{12} \mathrm{O}_{3}\right)$ and glucose $\left(108.1212 \mathrm{Da}, \mathrm{C}_{6} \mathrm{H}_{12} \mathrm{O}_{6}\right)$ respectively. Similarly, fragments b2 $\left(108.1212 \mathrm{Da}, \mathrm{C}_{7} \mathrm{H}_{8} \mathrm{O}\right)$ and b4 $\left(124.1348 \mathrm{Da}, \mathrm{C}_{7} \mathrm{H}_{8} \mathrm{O}_{2}\right)$ were assigned to the products arising from the cleavage of resveratrol $(\mathrm{b} 1,228.1447 \mathrm{Da}$, $\mathrm{C}_{14} \mathrm{H}_{12} \mathrm{O}_{3}$ ). These structural assignments were supported by the presence of fragment b3 $\left(\mathrm{C}_{13} \mathrm{H}_{18} \mathrm{O}_{7}\right)$, which would result from glucose (b5) combining with fragment b4.

A similar strategy was used to confirm the structures of the combretastatins. Fragmentation of the compound identified as combretastatin A-1 yielded peaks corresponding to the molecular ion mass (332.1319 Da) as well as fragments corresponding to 182.1872 and $152.1445 \mathrm{Da}$. The molecular formulae $\mathrm{C}_{10} \mathrm{H}_{14} \mathrm{O}_{3}$ and $\mathrm{C}_{8} \mathrm{H}_{8} \mathrm{O}_{3}$ were assigned for these 


\begin{tabular}{|c|c|c|c|c|c|c|}
\hline & \multicolumn{2}{|r|}{ Piceid } & \multicolumn{2}{|c|}{ Combretastatin A-1 } & \multicolumn{2}{|c|}{ Combretastatin A-4 } \\
\hline & MW (Da) & Empirical formula & MW (Da) & Empirical formula & MW (Da) & Empirical formula \\
\hline MW (calculated) & 404.4105 & $\mathrm{C}_{21} \mathrm{H}_{24} \mathrm{O}_{8}$ & 332.3478 & $\mathrm{C}_{18} \mathrm{H}_{20} \mathrm{O}_{6}$ & 316.3484 & $\mathrm{C}_{18} \mathrm{H}_{20} \mathrm{O}_{5}$ \\
\hline MW (measured $\mathrm{M}^{+}$) & 404.1465 & $\mathrm{C}_{21} \mathrm{H}_{24} \mathrm{O}_{8}$ & 332.1319 & $\mathrm{C}_{18} \mathrm{H}_{20} \mathrm{O}_{6}$ & 316.1287 & $\mathrm{C}_{18} \mathrm{H}_{20} \mathrm{O}_{5}$ \\
\hline \multirow[t]{5}{*}{ MW of prominent peaks } & 286.1453 & $\mathrm{C}_{13} \mathrm{H}_{18} \mathrm{O}_{7}$ (b3) & 182.1872 & $\mathrm{C}_{10} \mathrm{H}_{14} \mathrm{O}_{3}(\mathrm{c} 2)$ & 182.1788 & $\mathrm{C}_{10} \mathrm{H}_{14} \mathrm{O}_{3}(\mathrm{~d} 1)$ \\
\hline & 270.0472 & $\mathrm{C}_{6} \mathrm{H}_{12} \mathrm{O}_{6}(\mathrm{~b} 5)$ & 152.1445 & $\mathrm{C}_{8} \mathrm{H}_{8} \mathrm{O}_{3}(\mathrm{c} 1)$ & 138.1463 & $\mathrm{C}_{8} \mathrm{H}_{10} \mathrm{O}_{2}(\mathrm{~d} 2)$ \\
\hline & 228.1447 & $\mathrm{C}_{14} \mathrm{H}_{12} \mathrm{O}_{3}$ (b1) & & & & \\
\hline & 124.1348 & $\mathrm{C}_{7} \mathrm{H}_{8} \mathrm{O}_{2}(\mathrm{~b} 4)$ & & & & \\
\hline & 108.1212 & $\mathrm{C}_{7} \mathrm{H}_{8} \mathrm{O}(\mathrm{b} 2)$ & & & & \\
\hline
\end{tabular}

$b_{1}, b_{2}, b_{3}, b_{4}, b_{5}, c_{1}, c_{2}, d_{1}, d 2$ refer to the molecular fragments shown in Figure 6. MW: Molecular weight

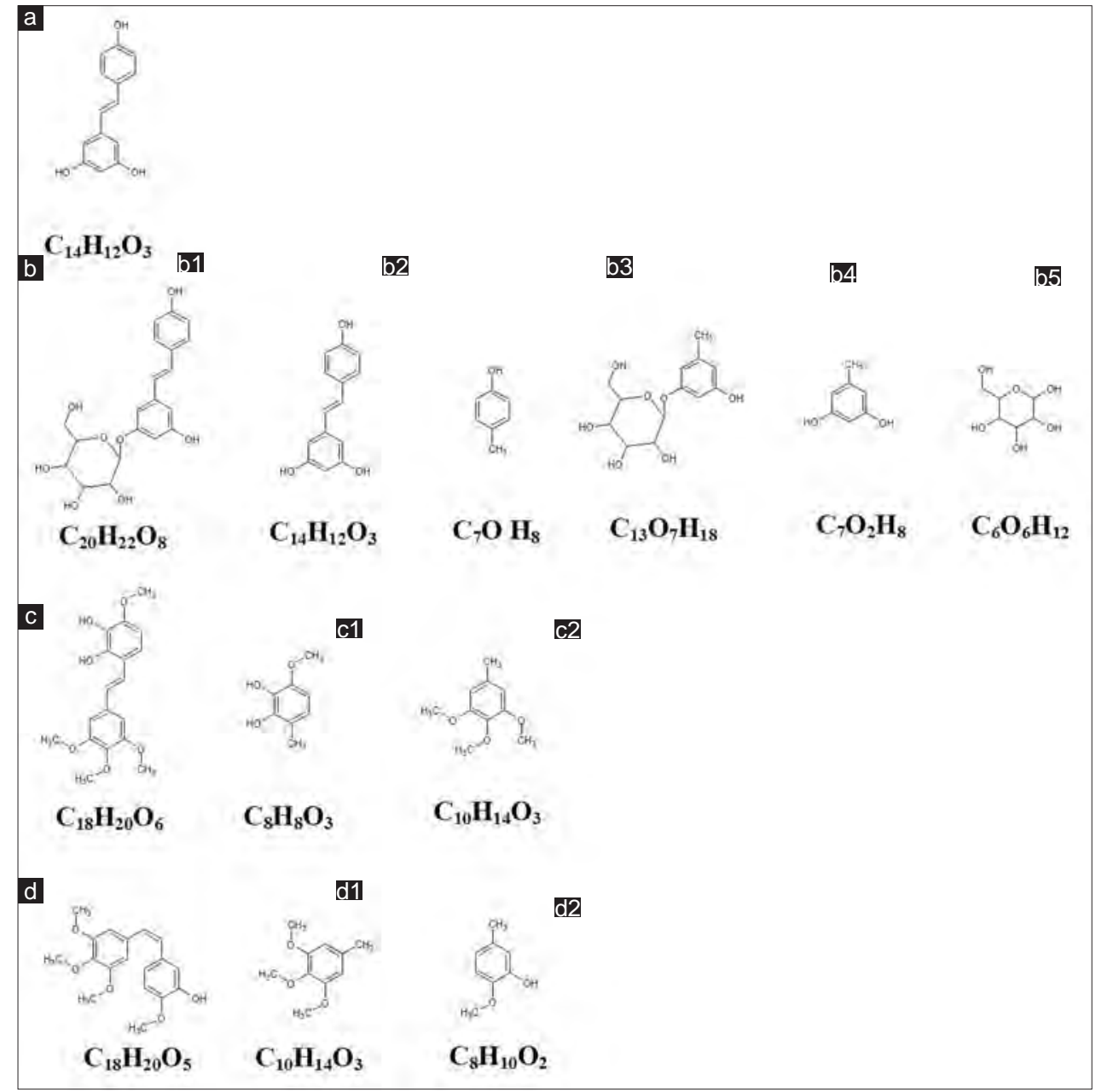

Figure 6: Chemical structures of (a) resveratrol and the stilbenes and stilbene glycosides identified in Tasmannia lanceolata extracts: (b) piceid, (c) combretastatin A-1, (d) combretastatin A-4. (b1-b5) represent the molecular weight fragments of piceid detected by ESI-MS in positive mode; (c1-c2) represent the molecular weight fragments of combretastatin A-1 detected by ESI-MS in positive mode; (d1-d2) represent the molecular weight fragments of combretastatin A-4 detected by ESI-MS in positive mode

fragments, respectively. Comparison with the molecular mass databases indicated the putative structures of these fragments [Figure 6c1 and 6c2]. These fragments were assigned to the cleavage of combretastatin A-1 (332.1319 $\left.\mathrm{Da}, \mathrm{C}_{18} \mathrm{H}_{20} \mathrm{O}_{6}\right)$ to $182.1872 \mathrm{Da}\left(\mathrm{C}_{10} \mathrm{H}_{14} \mathrm{O}_{3}\right)$ and 152.1445 $\mathrm{Da}\left(\mathrm{C}_{8} \mathrm{H}_{8} \mathrm{O}_{3}\right)$ fragments.
The compound putatively identified as combretastatin A-4 [Figure 6d; 316.1287 Da, $\mathrm{C}_{18} \mathrm{H}_{20} \mathrm{O}_{5}$ ] also fragmented, giving $182.1788 \mathrm{Da}\left(\mathrm{C}_{10} \mathrm{H}_{14} \mathrm{O}_{3}\right)$, providing further evidence of the structural similarity of the compounds putatively identified as combretastatins A-1 and A-4. A further fragment $(138.1463 \mathrm{Da})$ was detected in the fragmentation 
of combretastatin A-4. The molecular formula $\mathrm{C}_{8} \mathrm{H}_{10} \mathrm{O}_{2}$ was assigned to this fragment by comparison with the molecular mass databases. From a comparison of the proposed fragmentation patterns with the putative molecular ion structure, it is evident that the combretastatin A-4 structure is consistent with these results.

\section{DISCUSSION}

Plant remedies are becoming increasingly sought after in the treatment of a myriad of diseases and disorders due to their perception of greater safety than synthetic drugs, as well as the failure of current drug regimes to effectively treat many diseases. This is especially true for RA. The current treatments utilizing DMARDs to alleviate the symptoms of RA and/or alter the disease progression are not entirely effective and have been associated with numerous adverse effects. ${ }^{[2]}$ Furthermore, many of the current treatments are aimed at treating the symptoms of RA without addressing the underlying causes and disease mechanisms. An understanding of the initiation and progression of RA is important to allow for the development of new drugs to target specific processes and thus more effectively treat the disease.

The role of $P$. mirabilis infection as a trigger of RA is now widely accepted due to a wealth of supporting evidence. ${ }^{[15]}$ A treatment regime targeting the microbial trigger of RA is an attractive prospect as it would be expected to block/ decrease production of self-reactive antibodies and thus effectively block disease progression. The results presented here demonstrate the ability of a wide variety of plants traditionally used to treat RA and inflammatory complaints in Australian Aboriginal medicinal systems to inhibit P. mirabilis growth when tested in the forms that they would have been used in traditional medicine (decoctions and tinctures). Further quantification by MIC determination demonstrated the efficacy of these extracts as inhibitors of the microbial trigger of RA. The T. lanceolata extracts were of particular interest, with MIC's as low as $11 \mu \mathrm{g} / \mathrm{ml}(0.11 \mu \mathrm{g}$ in the disc) for the methanolic fruit extracts. Indeed, these extracts proved to be substantially stronger than the control antibiotics (ampicillin and chloramphenicol) and are thus worthy of further mechanistic studies. The current study was limited to the inhibitory activity toward the microbial trigger of RA. It is possible that many of the plant extracts studied here may also have effects on other inflammatory processes (e.g. cytokine release) and, therefore, may have pluripotent anti-RA mechanisms.

The major anti-inflammatory components of many medicinal plants are known and are already available in a pure form as anti-inflammatory agents. These compounds include a variety of polyphenolic compounds, of which 3,5,4'-trihydroxy-trans-stilbene (resveratrol) has received much recent attention. ${ }^{[45]}$ Most studies examining the role of resveratrol in the treatment of RA concern its ability to act as a potent specific inhibitor of nuclear factor (NF)- $\mathrm{BB}$ activation through its induction by tumor necrosis factor alpha and interleukin-1 beta (IL-1 $\beta$ ). ${ }^{[4]}$ Thus, resveratrol treatment is known to block cytokine production and inflammation via its inhibition of NF-KB activation. However, it is possible that resveratrol may also have other anti-rheumatic effects as it also has antibacterial activity against a variety of bacterial species. ${ }^{[46]}$ It was therefore thought likely that it may also function to block the microbial trigger of RA and the plant extracts examined in this study were screened for its presence.

Interestingly, while resveratrol has been reported to have inhibitory activity against other bacterial species, it was unable to inhibit the growth of $P$. mirabilis in our studies, even at high concentrations (unreported results). Furthermore, we were unable to find any reports of in vitro anti-Proteus growth inhibition in the published literature. Several studies have reported on the ability of resveratrol to inhibit P. mirabilis swarming and virulence factor expression in vivo, so it is likely that resveratrol does affect $P$. mirabilis colonization and infection of the urinary tract, ${ }^{[4]}$ albeit possibly by mechanisms other than bactericidal or growth inhibition mechanisms. Any extracts that were capable of inhibiting Proteus spp. growth and also contained the resveratrol would be likely to have anti-RA activity via several mechanisms (growth inhibition, colonization blocking, cytokine production inhibition) and, therefore, would be particularly effective in treating RA.

High accuracy HPLC-MS/MS analysis of the T. lanceolata fruit extracts failed to detect resveratrol in either extract. However, it is possible that resveratrol may still contribute to the anti-inflammatory activities of these extracts. The resveratrol glycoside Piceid (2-[3-hydroxy-5[(E)-2-(4-hydroxyphenyl) ethenyl] phenoxy]-6-(hydroxymethyl) oxane-3,4,5-triol) was detected in both $T$. lanceolata fruit extracts. Piceid may be hydrolysed in vivo to remove glucose, thus releasing the resveratrol moiety. Furthermore, while other resveratrol glycosides like polydatin were not detected by matching with the compound databases used in these studies, it is possible that they may still be present in small quantities. Piceid and other glycosylated stilbenes (if present) may also contribute to the anti-inflammatory activity of T. lanceolata fruit extracts via mechanisms other than Proteus growth inhibition. Several glycosylated stilbenes (including Piceid) have both been shown to block inflammation by decreasing IL-17 production in stimulated human mononuclear cells. ${ }^{[48]}$ Another study ${ }^{[49]}$ determined that the antibacterial 
activity of resveratrol is due to a protein tyrosine kinase activity. This same study also reported that resveratrol glycosides do not have the same bacterial inhibitory activity, indicating that free hydroxyl groups on both phenyl groups are required for antibacterial activity.

In addition to Piceid, other stilbenes were also detected in the T. lanceolata fruit extracts. Combretastatins A -1 and A -4 were detected in both $T$. lanceolata fruit extracts, although the relatively low peak sizes indicate that both compounds are present in low abundance. Combretastatins are well -known for their potent ability to block cancer cell progression and induce apoptosis by binding intracellular tublin, thereby disrupting microtubule formation. ${ }^{[5]}$ Accounts of direct anti -inflammatory activity of combretastatins are lacking. However, it is believed that they act by a similar mechanism to that of colchicine $(\mathrm{N}-[(7 \mathrm{~S})-1,2,3,10$-tetramethoxy -9 -oxo -5,6,7,9 -tetrahydrobenzo[a] heptlen - 7 -yl] acetamide) by binding the colchicine binding site on the tubulin peptide and inhibiting polymerization. ${ }^{[51]} \mathrm{It}$ is likely that they may have a similar anti -inflammatory activity and mechanism to colchicine.

We were also unable to find accounts of the antibacterial activities of natural combretastatins in the literature. However, recent studies have examined the growth inhibitory activity of several synthetic combretastatin and resveratrol structural analogues. ${ }^{[52]}$ These studies reported potent growth inhibition toward a panel of bacteria including Staphylococcus aureus, Streptococcus pneumoniae, Escherichia coli, and Neisseria gonorrboeae. Especially interesting was the low MIC values of some analogues against N. gonorrhoeae, although several other species were also highly susceptible to the modified stilbenes. The same study also reported potent inhibitory effects of the panel of modified stilbenes against the fungal species Candida albicans and Cryptococcus neoformans.

A number of other inflammatory stilbenes have also previously been reported in other plant species. For example, 2,3,4,5-tetrahydroxystilbene-2-O- $\beta$-D-gluco side (TSG) inhibits inflammation by suppressing the induction of pro-inflammatory mediators by reducing NF-KB binding to DNA. ${ }^{[53]}$ The same study detected TSG in numerous herbs used to treat inflammation in Chinese traditional medicine. Furthermore, nine stilbene and stilbene derivatives isolated from the roots of Cicer spp. (chickpeas) were shown to inhibit bacterial and fungal growth. ${ }^{[54]}$ While these compounds were not detected in the compound databases used in our studies, it is possible that they may still be present in small quantities.

It is likely that other phytochemical classes may also contribute to the anti-inflammatory properties of these extracts. Alkaloids, anthraquinones, flavonoids, polyphenolics, phytosterols, saponins, tannins, and terpenes have also been linked with anti-bacterial activity in different plant species and thus may be responsible (at least in part) for the anti-anti-Proteus activities reported here. Several terpenoids previously reported in T. lanceolata fruit extracts have been reported to suppress NF-KB signaling (the major regulator of inflammatory diseases). ${ }^{[5]}$ The monoterpenes limonene ${ }^{[56,57]}$ and $\alpha$-pinene ${ }^{[58]}$ have been reported to inhibit NF- $\kappa \mathrm{B}$ signaling pathways. $\alpha$-Pinene affects inflammation by inhibiting p65 translocation into the nucleus in Lipopolysacccharide-induced NF- $\mathrm{KB}$ signaling. ${ }^{[58]}$ Furthermore, many other sesquiterpenes and sesquiterpene lactones also have well-established anti-inflammatory activities ${ }^{[55]}$ While much work is still needed to characterize the mechanisms of action of these compounds, it appears that NF- $\mathrm{KB}$ inhibitory activities may be responsible.

The antimicrobial activity of Drimys winteri (a species closely related to $T$. lanceolata) essential oils has been well-documented against a variety of bacterial species, and it has been established that terpenoids contribute to this activity. ${ }^{[5]}$ Drimys winteri essential oils contain many of the same monoterpenoid constituents as T. lanceolata essential oils (including polygoidal, $\alpha$-pinene, $\beta$-pinene, sabinene, mycrene, terpinene, limonene, and $\beta$-phellandrene). That study demonstrated good antibacterial activities for all of these compounds. Further studies have also shown that the monoterpene piperitone reduces the resistance of several strains of Enterobacteriaceae to the antibacterial agent nitrofurantoin. ${ }^{[60]}$ Other studies have reported similar antibacterial activities for the sesquiterpenoids $\alpha$-cubebene, copaene, and caryophyllene isolated from Pilgerodendron uviferum. ${ }^{[61]}$

This study was limited to an examination of the phytochemistry of the most potent $P$. mirabilis growth inhibitor. Further studies are needed to examine the compounds present in the other highly potent extracts. Specifically, the A. moluccanus, D. leichardtii, E. major, L. bracteata, L. juniperium, M. integriflora nut, M. alternifolia, M. quinquenervia, P. pubescens, $P$. triloculorae, $P$. augustifolium, $S$. spinescens and $S$. australe extracts should also be screened for the presence of stilbenes.

The findings reported here also demonstrate that the majority of plant extracts tested did not display significant toxicity in the Artemia nauplii bioassay. Indeed, with the exception of some Eucalyptus and Syzygium extracts, all other extracts exhibiting Proteus inhibitory activity were also shown to be nontoxic, or of low toxicity in the Artemia nauplii bioassay. Only extracts from these species displayed $\mathrm{LC}_{50}$ values below $1000 \mu \mathrm{g} / \mathrm{ml}$ and 
therefore all other plant extracts that inhibit $P$. mirabilis growth are defined as nontoxic as compounds with an $\mathrm{LC}_{50}$ of $>1000 \mu \mathrm{g} / \mathrm{ml}$ toward Artemia nauplii have been previously defined as being nontoxic. ${ }^{[41]}$ However, even the Eucalyptus spp. extracts (with LC50 values generally $>650 \mu \mathrm{g} / \mathrm{ml}$ ) are considered of only moderate toxicity.

\section{CONCLUSIONS}

The results of this study partially validate the usage of these plants in traditional Australian Aboriginal medicinal systems to treat RA and other inflammatory conditions and indicate that the phytochemistry and mechanism of action are worthy of further study. Similarly, it is also of interest to screen these extracts for further activities associated with the treatment of RA (e.g. inhibition of cytokine production) to further evaluate their potential as anti-RA drugs. While the extracts examined in this report are promising as anti-RA agents, caution is needed before these compounds can be applied to medicinal purposes. In particular, further toxicity studies using human cell lines are needed to verify the suitability of these extracts for these purposes.

\section{ACKNOWLEDGMENTS}

The authors are grateful to Philip Cameron, senior botanic officer, at the Brisbane Botanical Gardens Mt Cootha, Australia, for providing and identifying many of the plant materials used in these studies. Financial support for this work was provided by the Environmental Futures Research Institute, and the School of Natural Sciences, Griffith University Australia.

\section{REFERENCES}

1. Lawrence RC, Helmick CG, Arnett FC, Deyo RA, Felson DT, Giannini EH, et al. Estimates of the prevalence of arthritis and selected musculoskeletal disorders in the United States. Arthritis Rheum 1998;41:778-99.

2. Aletaha D, Kapral T, Smolen JS. Toxicity profiles of traditional disease modifying antirheumatic drugs for rheumatoid arthritis. Ann Rheum Dis 2003;62:482-6.

3. Nepom GT, Byers P, Seyfried C, Healey LA, Wilske KR, Stage D, et al. HLA genes associated with rheumatoid arthritis. Identification of susceptibility alleles using specific oligonucleotide probes. Arthritis Rheum 1989;32:15-21.

4. Rashid T, Darlington G, Kjeldsen-Kragh J, Forre O, Collado A, Ebringer A. Proteus IgG antibodies and C-reactive protein in English, Norwegian and Spanish patients with rheumatoid arthritis. Clin Rheumatol 1999;18:190-5.

5. Blankenberg-Sprenkels SH, Fielder M, Feltkamp TE, Tiwana $\mathrm{H}$, Wilson C, Ebringer A. Antibodies to Klebsiella pneumoniae in Dutch patients with ankylosing spondylitis and acute anterior uveitis and to Proteus mirabilis in rheumatoid arthritis. J Rheumatol 1998;25:743-7.
6. Chou CT, Uksila J, Toivanen P. Enterobacterial antibodies in Chinese patients with rheumatoid arthritis and ankylosing spondylitis. Clin Exp Rheumatol 1998;16:161-4.

7. Subair $\mathrm{H}$, Tiwana $\mathrm{H}$, Fielder $\mathrm{M}$, Binder $\mathrm{A}$, Cunningham $\mathrm{K}$, Ebringer $\mathrm{A}$, et al. Elevation in anti-Proteus antibodies in patients with rheumatoid arthritis from Bermuda and England. J Rheumatol 1995;22:1825-8.

8. Wanchu A, Deodhar SD, Sharma M, Gupta V, Bambery P, Sud A. Elevated levels of anti-Proteus antibodies in patients with active rheumatoid arthritis. Indian J Med Res 1997;105:39-42.

9. Senior BW, McBride PD, Morley KD, Kerr MA. The detection of raised levels of IgM to Proteus mirabilis in sera from patients with rheumatoid arthritis. J Med Microbiol 1995;43:176-84.

10. Rashid T, Ebringer A. Rheumatoid arthritis is caused by asymptomatic Proteus urinary tract infections. In: Nikibakhsh A, editor. Clinical Management of Complicated Urinary Tract Infection. Vol. 11. Rijeka, Croatia: In-Tech; 2011.

11. Senior BW, Anderson GA, Morley KD, Kerr MA. Evidence that patients with rheumatoid arthritis have asymptomatic 'non-significant' Proteus mirabilis bacteriuria more frequently than healthy controls. J Infect 1999;38:99-106.

12. Ebringer A, Ptaszynska $T$, Corbett M, Wilson C, Macafee $\mathrm{Y}$, Avakian $\mathrm{H}$, et al. Antibodies to Proteus in rheumatoid arthritis. Lancet 1985;2:305-7.

13. Ebringer $A$, Cunningham $P$, Ahmadi $K$, Wrigglesworth $J$, Hosseini R, Wilson C. Sequence similarity between HLA-DR1 and DR4 subtypes associated with rheumatoid arthritis and Proteus/Serratia membrane haemolysins. Ann Rheum Dis 1992;51:1245-6.

14. Wilson $\mathrm{C}$, Ebringer $\mathrm{A}$, Ahmadi $\mathrm{K}$, Wrigglesworth $\mathrm{J}$, Tiwana $\mathrm{H}$, Fielder $\mathrm{M}$, et al. Shared amino acid sequences between major histocompatibility complex class II glycoproteins, type XI collagen and Proteus mirabilis in rheumatoid arthritis. Ann Rheum Dis 1995; 54:216-20.

15. Ebringer A, Rashid T. Rheumatoid arthritis is an autoimmune disease triggered by Proteus urinary tract infection. Clin Dev Immunol 2006;13:41-8.

16. Wang M, Guo Q, Xu X, Wang X, Ye X, Wu S, et al. New plasmid-mediated quinolone resistance gene, qnrC, found in a clinical isolate of Proteus mirabilis. Antimicrob Agents Chemother 2009;53:1892-7.

17. Liaw SJ, Lai HC, Ho SW, Luh KT, Wang WB. Characterisation of p-nitrophenylglycerol-resistant Proteus mirabilis super-swarming mutants. J Med Microbiol 2001;50:1039-48.

18. Lee $\mathrm{H}$, Ko KS, Song $\mathrm{JH}$, Peck KR. Antimicrobial activity of doripenem and other carbapenems against gram-negative pathogens from Korea. Microb Drug Resist 2011;17:37-45.

19. Disaanayake DM, Faoagali J, Laroo H, Hancock G, Whitehouse M. Efficacy of some colloidal silver preparations and silver salts against Proteus bacteria, one possible cause of rheumatoid arthritis. Inflammopharmacology 2014;22:73-7.

20. Cock IE, van Vuuren SF. Anti-Proteus activity of some South African medicinal plants: Their potential for the prevention of rheumatoid arthritis. Inflammopharmacology 2014;22:23-36.

21. Cock IE. Medicinal and aromatic plants - Australia. In: Ethnopharmacology, Encyclopedia of Life Support Systems (EOLSS) 2011. Developed Under the Auspices of UNESCO. Oxford UK: EOLSS Publishers; 2011. Available from: http://www.eolss.net. [Last accessed 2014 Oct 7].

22. Lassak EV, McCarthy T. Australian Medicinal Plants. Australia: New Holland Publishers; 2011.

23. Netzel M, Netzel G, Tian Q, Schwartz S, Konczak I. Native Australian fruits - A novel source of antioxidants for food. Innov Food Sci Emerg Technol 2007;8:339-46. 
24. Winnett $\mathrm{V}$, Boyer $\mathrm{H}$, Sirdaarta J, Cock IE. The potential of Tasmannia lanceolata as a natural preservative and medicinal agent: Antimicrobial activity and toxicity. Pharmacogn Commun 2014;4:42-52.

25. Cock IE. Antimicrobial activity of Acacia aulacocarpa and Acacia complanta methanolic extracts. Pharmacogn Commun 2012;2:66-71.

26. Cock IE. Antimicrobial activity of Callistemon citrinus and Callistemon salignus methanolic extracts. Pharmacogn Commun 2012;2:50-7.

27. Cock IE. Antibacterial activity of selected Australian native plant extracts. Internet J Microbiol 2008;4.

28. Cock IE. Antibacterial activity of Eucalyptus major and Eucalyptus baileyana methanolic extracts. Internet J Microbiol $2009 ; 6$.

29. Cock IE. Antimicrobial activity of Leptospermum bracteata and Leptospermum juniperium methanolic extracts. Pharmacogn Commun 2013;3:45-52.

30. Sautron C, Cock IE. Antimicrobial activity and toxicity of Syzygium australe and Syzygium leuhmannii fruit extracts. Pharmacogn Commun 2014;4:53-60.

31. Chikowe G, Mpala L, Cock IE. Antibacterial activity of selected Australian Syzygium species. Pharmacogn Commun 2013;3:77-83.

32. Cock IE. Antimicrobial activity of Syzygium australe and Syzygium leuhmannii leaf methanolic extracts. Pharmacogn Commun 2012;2:71-7.

33. Vesoul J, Cock IE. An examination of the medicinal potential of Pittosporum phylliraedes: Toxicity, antibacterial and antifungal activities. Pharmacogn Commun 2011;1:8-17.

34. Kalt FR, Cock IE. Gas chromatography-mass spectroscopy analysis of bioactive Petalostigma extracts: Toxicity, antibacterial and antiviral activities. Pharmacogn Mag 2014;10:S37-49.

35. Cock IE, Kukkonen L. An examination of the medicinal potential of Scaevola spinescens: Toxicity, antibacterial, and antiviral activities. Pharmacognosy Res 2011;3:85-94.

36. Cock IE, Mohanty S. Evaluation of the antibacterial activity and toxicity of Terminalia ferdinandiana fruit extracts. Pharmacogn $\mathrm{J}$ 2011;3:72-9.

37. Kalt FR, Cock IE. The medicinal potential of Australian native plants from Toohey Forest, Australia. South Pac J Nat Appl Sci 2010;28:41-7.

38. Sirdaarta J, Cock IE. Effect of Aloe barbadensis Miller juice on oxidative stress biomarkers in aerobic cells using Artemia franciscana as a model. Phytother Res 2010;24:360-4.

39. Sirdaarta J, Cock IE. Vitamin E and Trolox ${ }^{\mathrm{TM}}$ reduce toxicity of Aloe barbadensis Miller juice in Artemia franciscana nauplii but individually are toxic at high concentrations. Internet $\mathrm{J}$ Toxicol 2008;5.

40. Cock IE. Assessment of the toxicity of selected Australian native plant extracts using the Artemia franciscana nauplii bioassay. Internet J Toxicol 2008;5.

41. Meyer BN, Ferrigni NR, Putnam JE, Jacobsen LB, Nichols DE, McLaughlin JL. Brine shrimp: A convenient general bioassay for active plant constituents. Planta Med 1982;45:31-4.

42. Kopp P. Resveratrol, a phytoestrogen found in red wine. A possible explanation for the conundrum of the 'French paradox'? Eur J Endocrinol 1998;138:619-20.

43. Joseph CC, Moshi MJ, Innocent E, Nkunya MH. Isolation of a stilbene glycoside and other constituents of Terminalia sericeae. Afr J Tradit Complement Altern Med 2007;4:383-6.

44. Poulnin KE, Schmalz HG, Polunina IA. Organometallic chemistry. Chromium arene complexes in synthesis of trans-resveratrol.
Russ Chem B+ (Int Ed) 2002;51:1319-24.

45. Elmali N, Baysal O, Harma A, Esenkaya I, Mizrak B. Effects of resveratrol in inflammatory arthritis. Inflammation 2007;30:1-6.

46. Paulo L, Ferreira S, Gallardo E, Queiroz JA, Domingues F. Antimicrobial activity and effects of resveratrol on human pathogenic bacteria. World J Microbiol Biotechnol 2010;26:1533-8.

47. Wang WB, Lai HC, Hsueh PR, Chiou RY, Lin SB, Liaw SJ. Inhibition of swarming and virulence factor expression in Proteus mirabilis by resveratrol. J Med Microbiol 2006;55:1313-21.

48. Lanzilli G, Cottarelli A, Nicotera G, Guida S, Ravagnan G, Fuggetta MP. Anti-inflammatory effect of resveratrol and polydatin by in vitro IL-17 modulation. Inflammation 2012;35:240-8.

49. Jayatilake GS, Jayasuriya $H$, Lee ES, Koonchanok NM, Geahlen RL, Ashendel CL, et al. Kinase inhibitors from Polygonum cuspidatum. J Nat Prod 1993;56:1805-10.

50. Dark GG, Hill SA, Prise VE, Tozer GM, Pettit GR, Chaplin DJ. Combretastatin A-4, an agent that displays potent and selective toxicity toward tumor vasculature. Cancer Res 1997;57:1829-34.

51. Bhardwaj S, Bakshi S, Chopra B, Dhingra A, Dhar KL. Synthesis of combretastatin analogues with their potent anticancer activity. Int J Res Pharm Sci 2010;1:414-6.

52. Pettit RK, Pettit GR, Hamel E, Hogan F, Moser BR, Wolf $\mathrm{S}$, et al. E-combretastatin and E-resveratrol structura modifications: Antimicrobial and cancer cell growth inhibitory beta-E-nitrostyrenes. Bioorg Med Chem 2009;17:6606-12

53. Huang $C$, Wang $Y$, Wang $J$, Yao $W$, Chen $X$, Zhang $W$. TSG (2,3,4',5-tetrahydroxystilbene 2-O- $\beta$-D-glucoside) suppresses induction of pro-inflammatory factors by attenuating the binding activity of nuclear factor- $\mathrm{\kappa B}$ in microglia. J Neuroinflammation 2013;10:129.

54. Aslam SN, Stevenson PC, Kokubun T, Hall DR. Antibacterial and antifungal activity of cicerfuran and related 2-arylbenzofurans and stilbenes. Microbiol Res 2009;164:191-5.

55. Salminen $A$, Lehtonen $M$, Suuronen $T$, Kaarniranta $K$, Huuskonen J. Terpenoids: Natural inhibitors of NF-kappaB signaling with anti-inflammatory and anticancer potential. Cell Mol Life Sci 2008;65:2979-99.

56. Lu XG, Zhan LB, Feng BA, Qu MY, Yu LH, Xie JH. Inhibition of growth and metastasis of human gastric cancer implanted in nude mice by d-limonene. World J Gastroenterol 2004;10:2140-4.

57. Crowell PL. Prevention and therapy of cancer by dietary monoterpenes. J Nutr 1999;129:775S-8.

58. Zhou JY, Tang FD, Mao GG, Bian RL. Effect of alpha-pinene on nuclear translocation of NF-kappa B in THP-1 cells. Acta Pharmacol Sin 2004;25:480-4.

59. Santos TG, Dognini J, Begnini IM, Rebelo RA, Verdi M, de Gasper AL, et al. Chemical characterisation of essential oils from Drimys angustifolia miers (Winteraceae) and antibacterial activity of their major compounds. J Braz Chem Soc 2013;24:164-70.

60. Shahverdi AR, Rafii F, Tavassoli F, Bagheri M, Attar F, Ghahraman A. Piperitone from Mentha longifolia var. chorodictya Rech $F$. reduces the nitrofurantoin resistance of strains of enterobacteriaceae. Phytother Res 2004;18:911-4.

61. Solis C, Becerra J, Flores C, Robledo J, Silva M. Antibacterial and antifungal terpenes from Pilgerodendron uviferum (D. Don) Florin. J Chil Chem Soc 2004;49:157-61.

62. Cock IE. Antimicrobial activity of Backhousia citriodora (lemon myrtle) methanolic extracts. Pharmacogn Commun 2013;3:58-63.

63. Cock IE. Problems of reproducibility and efficacy of bioassays with special reference to Aloe vera. Pharmacognosy Communications 2011;1:52-62. 
64. Boyer H, Cock IE. Evaluation of the potential of Macadamia integriflora extracts as antibacterial food agents. Pharmacogn Commun 2013;3:53-62.

65. Cock IE. The phytochemistry and chemotherapeutic potential of Tasmannia lanceolata (Tasmanian pepper): A review. Pharmacogn Commun 2013;3:13-25.
Cite this article as: Cock IE, Winnett V, Sirdaarta J, Matthews B. The potential of selected Australian medicinal plants with anti-Proteus activity for the treatment and prevention of rheumatoid arthritis. Phcog Mag 2015;11:190-208.

Source of Support: Financial support for this work was provided by the Environmental Futures Research Institute, and the School of Natural Sciences, Griffith University Australia. Conflict of Interest: None declared. 